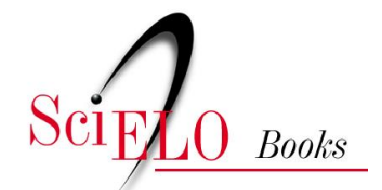

\title{
Escola do Meio Ambiente Com Vida
}

\author{
Elizabeth M. dos Santos Schmidt \\ Eliana Maria Nicolini Gabriel
}

SciELO Books / SciELO Livros / SciELO Libros

SCHMIDT, SEM., and GABRIEL, EMN. Escola do Meio Ambiente Com Vida [online]. São Paulo: Cultura Acadêmica, 2016. 83 p. ISBN: 978-85-7983-757-9. Available from: doi: 10.7476/9788579837579. Also available in ePUB from: http://books.scielo.org/id/ckwyb/epub/schimidt-9788579837579.epub

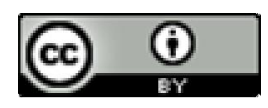

All the contents of this work, except where otherwise noted, is licensed under a Creative Commons Attribution 4.0 International license.

Todo o conteúdo deste trabalho, exceto quando houver ressalva, é publicado sob a licença Creative Commons Atribição 4.0.

Todo el contenido de esta obra, excepto donde se indique lo contrario, está bajo licencia de la licencia $\underline{\text { Creative Commons }}$ Reconocimento 4.0. 


\section{Escola DO \\ Meio Ambiente COM VIDA}




$$
\begin{gathered}
\text { Realização } \\
\text { Pró-reitoria de Extensão Universitária (Proex) } \\
\text { Rua Quirino de Andrade, 215 - 10 andar } \\
\text { 01049-010 - São Paulo - SP }
\end{gathered}
$$

Dirigentes da Universidade Estadual Paulista "Júlio de Mesquita Filho" http://www.unesp.br/portal\#!/reitoria_ses/dirigentes-da-unesp/

Conselho Editorial da Pró-reitoria de Extensão Universitária

Prof. Dr. Cláudio Cesar de Paiva - FCL/Araraquara

Prof. Dr. Eduardo Galhardo - FCL/Assis

Prof. Dr. José Arnaldo Frutuoso Roveda - ICT/Sorocaba

Profa Dra Márcia Pereira da Silva - FCHS/Franca

Profa Dra Maria Cândida Soares Del Masso - FFC/Marília

Profa Dra Rosane Michelli de Castro - FFC/Marília

Prof. Dr. Sebastião Souza Lemes - FCL/Araraquara

Comissão de Avaliação definida pela Pró-reitoria de Extensão Universitária da Unesp

Profa Dra Ana Paula Cordeiro - FFC/Marília

Prof. Dr. Antônio Cézar Leal - FCT/Presidente Prudente

Profa Dra Camila Pires Cremasco Gabriel - FCE/Tupã

Profa Dra Eliana Marques Zanata - FC/Bauru

Prof. Dr. José Carlos Miguel - FFC/Marília

Profa Dra Luciene Cristina Risso - CE/Ourinhos

Profa Dra Maria do Carmo Kobayashi - FC/Bauru

Prof. Dr. Mário Lázaro Camargo - FC/Bauru

Profa Dra Nanci Soares - FCHS/Franca

Profa Dra Rosa Maria Feiteiro Cavalari - IB/Rio Claro

Profa Dra Tânia da Costa Garcia - FCHS/Franca

Profa Dra Tatiana Schneider Vieira de Moraes - FFC/Marília

Prof. Dr. Victor Hugo de Almeida - FCHS/Franca

Membros da Comissão Permanente de Extensão Universitária - CPEU da Faculdade de Medicina Veterinária e Zootecnia do Campus de Botucatu responsáveis pela indicação da obra

Profa Dra Alessandra Melchert

Prof. Dr. Carlos Roberto Teixeira

Profa Dra Maria Denise Lopes

Prof. Dr. Paulo Francisco Domingues

Prof. Dr. Ricardo de Oliveira Orsi 


\section{ELIZABETH M. DOS SANTOS SCHMIDT ELIANA MARIA NICOLINI GABRIEL}

\section{Escola \\ do Meio Ambiente \\ COM VIDA}

CULTURA $\frac{\text { ACADÊMICA }}{\varepsilon d i t o n a}$ 
(C) 2016 Editora Unesp

Cultura Acadêmica

Praça da Sé, 108

01001-900 - São Paulo - SP

Tel.: $(0 x \times 11)$ 3242-7171

Fax: $(0 x \times 11) 3242-7172$

www.editoraunesp.com.br

www.culturaacademica.com.br

www.livrariaunesp.com.br

feu@editora.unesp.br

CIP - Brasil. Catalogação na Publicação

Sindicato Nacional dos Editores de Livros, RJ

S362e

Schmidt, Elizabeth M. dos Santos

Escola do Meio Ambiente Com Vida / Elizabeth M. dos Santos

Schmidt, Eliana Maria Nicolini Gabriel. - 1. ed. - São Paulo : Cultura

Acadêmica, 2016.

recurso digital

Formato: ePDF

Requisitos do sistema: Adobe Acrobat Reader

Modo de acesso: World Wide Web

ISBN 978-85-7983-757-9 (recurso eletrônico)

1. Educação de crianças. 2. Meio ambiente. I. Gabriel, Eliana Maria Nicolini. II. Título.

$16-33272$

CDD: 372.2

CDU: 372.2

$\overline{\text { Este livro é publicado pelo Programa de Publicações da Pró-Reitoria de Extensão }}$ Universitária da Universidade Estadual Paulista "Júlio de Mesquita Filho" (UNESP)

Editora afiliada:
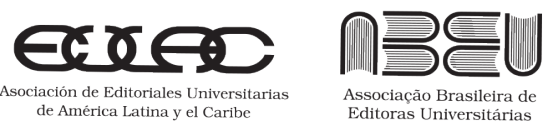


\section{SUMÁRIO}

Escola do Meio Ambiente: Com Vida 7

Escola Com Vida 9

Sobre a Escola do Meio Ambiente (EMA) 11

Floresta Municipal Irmãos Villas Bôas 13

Bosque Frei Afonso 15

Represa Prof. Jorge Jim 17

Metodologia 19

Alma-de-gato 25

Capivara 27

Cuíca 29

Gambá 33

Lobo-guará 37

Onça-parda 39 
6 ELIZABETH M. DOS SANTOS SCHMIDT • ELIANA MARIA NICOLINI GABRIEL

Ouriço-cacheiro 43

Periquitão-maracanã 45

Quero-quero 47

Rato-do-mato 51

Sabiá-laranjeira 53

Saracura 57

Serelepe 59

Tamanduá-bandeira 63

Tatu-galinha 67

Tucano 69

Fotos de alguns animais que frequentam as matas e as trilhas da EMA 73

Referências bibliográficas 81

Sobre as autoras 85 


\section{INTRODUÇÃO}

\section{Escola do Meio Ambiente: COM VIDA}

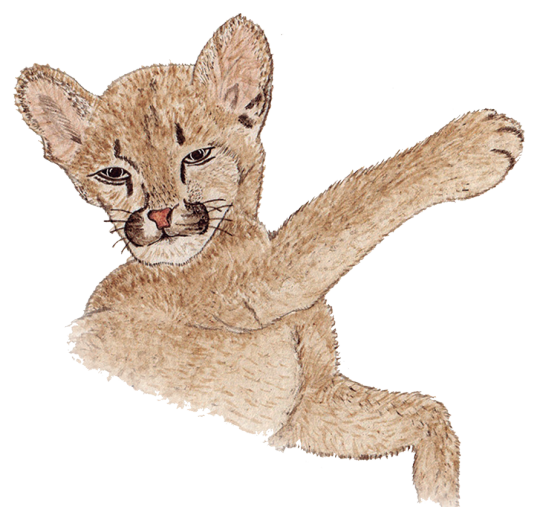

Esta publicação reúne o material desenvolvido na forma de cartilhas destinadas às crianças do primeiro ano do ensino fundamental da rede pública do município de Botucatu (SP) que visitam a Escola do Meio Ambiente (EMA). A EMA está situada em uma área composta por cerrado, floresta estacional semidecidual, mata paludosa e floresta implantada de eucalipto, abrigando nascentes e a represa abastecida pelo ribeirão Lavapés, que atravessa a zona urbana de Botucatu.

Trata-se de um local com trilhas destinadas à educação ambiental, onde as crianças têm a oportunidade de aprender sobre a importância de preservar e respeitar a natureza e os animais selvagens. As atividades de ensino ambiental fizeram com que a EMA fosse reconhecida como Escola Associada da Unesco. A partir de investigações realizadas em conjunto com a escola, foram obtidos 
dados da observação de animais silvestres que frequentam as matas e suas trilhas, por meio de visualização, vestígios, pelos seus rastros, além de imagens obtidas de câmeras fotográficas colocadas em diferentes locais no período noturno.

A segunda etapa do trabalho foi realizada por meio de pesquisa de referências científicas sobre os animais que vivem e que passam pela mata da escola, para que fossem criadas as histórias e as ilustrações de cada espécie. Assim, esta edição apresenta dezesseis narrativas com o objetivo de mostrar para as crianças que é preciso conhecer o lugar em que vivemos e ter uma relação com a natureza para conhecer as espécies animais que estão muito próximas: tatu-galinha, capivara, lobo-guará, sabiá-laranjeira, alma-de-gato, tamanduá-bandeira, tucano, quero-quero, suçuarana, periquitão-maracanã, serelepe, ouriço-cacheiro, cuíca, saracura, gambá e ratinho silvestre.

Elizabeth M. S. Schmidt

Professora e pesquisadora do

Departamento de Clínica Veterinária da Faculdade de Medicina Veterinária e Zootecnia Unesp, câmpus Botucatu 


\section{Escola Com VIDA}

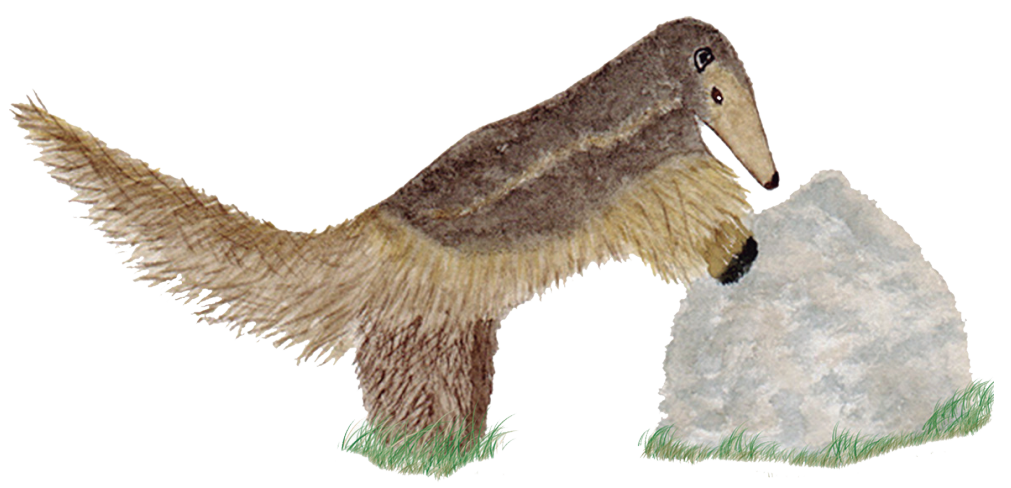

Muitas histórias ouvidas na infância permanecem conosco a vida toda. Por isso, quem as escreve tem a responsabilidade de se preocupar com os valores transmitidos ao público infantil. Encontramos este cuidado no coração da professora e médica veterinária Elizabeth Schmidt, autora das narrativas que seguem. Com sua sensibilidade, ela observa os animais e/ou os vestígios deixados por eles na área da Escola do Meio Ambiente, transformando suas observações em relatos repletos de encantos que nos convidam à leitura e ao aprendizado prazeroso.

Adentrando o universo infantil, por meio do resgate de sua própria infância, Elizabeth, em um momento particular de sua vida, produziu as histórias aqui contadas. Há no trabalho, também, a beleza singela das aquarelas da bióloga Sibele Gimenez Martins que mostram os hábitos de vida de cada animal. Para ilustrar as histórias, foi convidada Anna Clara Nicolini Gabriel, de 9 anos, que convive na Escola do Meio Ambiente.

A organização inicial deste material, na forma de cartilha, teve o apoio da Unimed/Botucatu, o que possibilitou que aproximadamente 2 mil crianças do primeiro ano do ensino fundamental da rede 
de ensino de Botucatu e região tivessem acesso direto a ele após participarem da Trilha do Jequitibá, na Escola do Meio Ambiente.

Vale ressaltar que ensinar pela palavra escrita é uma arte e também uma ferramenta utilizada há dez anos pela Escola do Meio Ambiente para que outras pessoas aprendam, assim como a professora Elizabeth, a amar e respeitar os animais e o local onde vivem.

Boa leitura a todos!

Abraço fraterno,

Eliana Maria Nicolini Gabriel Bióloga e diretora da Escola do Meio Ambiente do município de Botucatu 


\section{SOBRE A ESCOLA DO Meio Ambiente (EMA)}

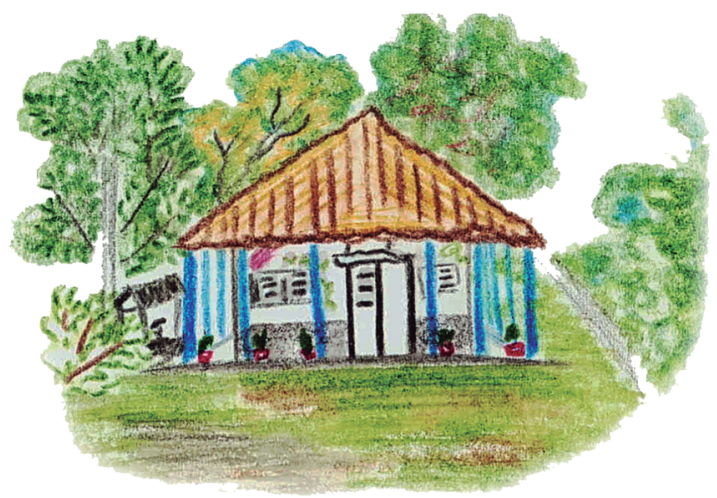

A Escola do Meio Ambiente localiza-se no município de Botucatu/SP e está sedimentada em três pilares principais: trilhas temáticas interpretativas, vivências socioambientais e pesquisas científicas. Contempla em sua área um mosaico de ecossistemas: floresta estacional semidecidual, mata paludosa, cerrado e floresta implantada de eucalipto, abrigando também as nascentes e a represa abastecida pelo ribeirão Lavapés, curso de água que atravessa a zona urbana de Botucatu. Recebe, anualmente, cerca de 15 mil alunos da rede de ensino do município em suas diferentes trilhas e vivências socioambientais.

A metodologia praticada na EMA foi desenvolvida a partir de sua própria realidade, tendo como inspiração a simplicidade da natureza, dissolvida nos pilares da escola.

Baseada no método peripatético (ensinar caminhando), a referida metodologia busca estabelecer, por meio de singelas vivências, um vínculo amoroso entre os visitantes e a Escola do Meio Ambiente. 
Deve ser lembrado que ninguém será capaz de amar o que não conhece e ninguém será capaz de preservar uma natureza com a qual não convive.

Assim, na EMA, tudo é preparado com muito carinho e responsabilidade para que esse vínculo possa ser estabelecido e, dessa forma, todos que passem pela Escola do Meio Ambiente compreendam o valor de se educar para a vida, pela paz e pela solidariedade planetária. O objetivo principal do método empregado há dez anos pela Escola do Meio Ambiente é o de mostrar a infinitude do valor pela vida. 


\section{Floresta Municipal IRMÃOS VILLAS BôAS}

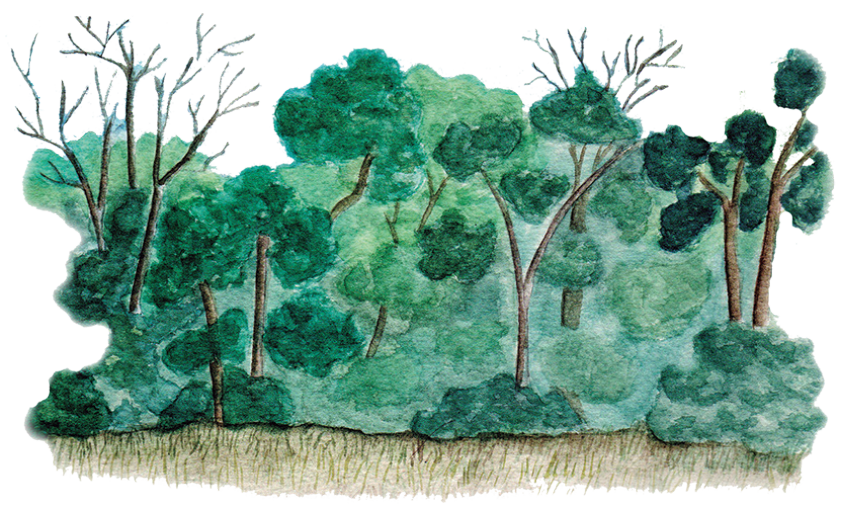

Nós trouxemos a notícia de que eles (os indios) constituem uma sociedade tranquila, alegre. Ali, ninguém manda em ninguém. $O$ velho é dono da história; o índio, dono da aldeia e a criança, dona do mundo.

Orlando Villas Bôas

Formada pelo remanescente de Floresta Estacional Semidecidual de aproximadamente 8 hectares encontrado na Escola do Meio Ambiente, a Floresta Municipal Irmãos Villas Bôas recebeu oficialmente essa denominação pela Lei Municipal n.5.287, de 6 de setembro de 2011.

A nomeação da floresta como Irmãos Villas Bôas é uma iniciativa da EMA em prol do Ano Internacional das Florestas e uma homenagem aos irmãos Leonardo, Orlando e Cláudio Villas Bôas, jovens que viveram em Botucatu, indigenistas e preservacionistas que 
deixaram sua terra para entrar na história, desbravando o Brasil central na Expedição Roncador-Xingu, em 1943.

Os irmãos Villas Bôas acreditavam que os conceitos de respeito e preservação observados pelo contato com as tribos indígenas são a base da preservação cultural desses povos. Tornaram-se sertanistas influentes, contribuindo com a política indigenista do Estado brasileiro ao longo dos últimos sessenta anos. 


\section{Bosoue Frei Afonso}

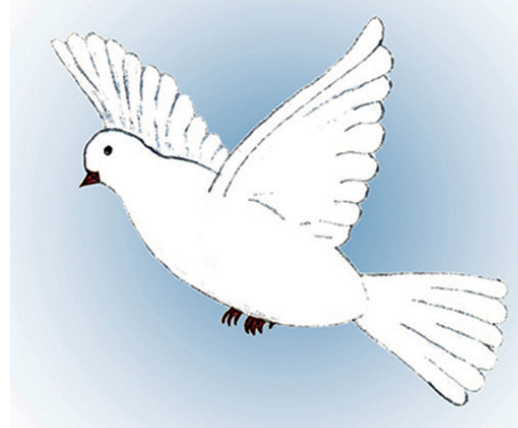

Frei Afonso viveu 86 anos, dos quais 67 foram de vida religiosa consagrada na Ordem dos Frades Menores Capuchinhos. Durante esse tempo, 62 anos foram de ministério sacerdotal. Na lembrança por ele elaborada e impressa por ocasião do $60^{\circ}$ aniversário de ordenação sacerdotal, assim escreveu:

Senhor, a todos os meus benfeitores, pais, parentes, frades, amigos, vivos e falecidos, dignai-vos retribuir com a vida eterna, a todos os que me fizeram e continuam fazendo o bem, a mim, vosso vilíssimo servo. SÓ A DEUS TODA HONRA E TODA GLÓRIA AGORA E PARA SEMPRE. AMÉM.

O Oratório dedicado a São Francisco de Assis, presente na entrada da Escola do Meio Ambiente, foi benzido pelo Frei Afonso, que já no primeiro contato com a área da referida escola mostrou um carinho especial pelo lugar. Sendo São Francisco o protetor da natureza, a Escola do Meio Ambiente, com o apoio da Câmara Municipal, pelos vereadores Luiz Aurélio Pagani e Luiz Francisco Fontes, 
16 ELIZABETH M. DOS SANTOS SCHMIDT • ELIANA MARIA NICOLINI GABRIEL

nomeou oficialmente pela Lei n.4.432, de 27 de novembro de 2012, o Bosque Educativo, elaborado com o patrocínio da Unimed, Sabesp e Duratex, com o nome de Frei Afonso, um frei tão querido em Botucatu. 


\section{Represa Prof. Jorge Jim}

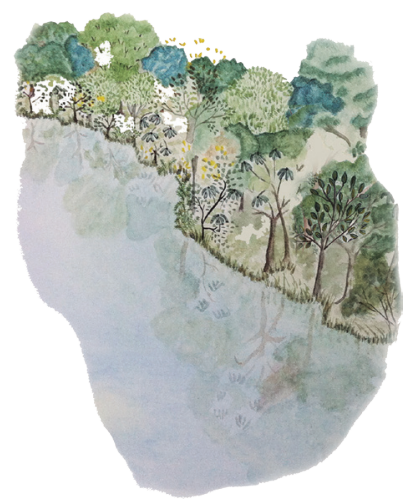

Abastecida com as águas do ribeirão Lavapés, a Represa Prof. Jorge Jim recebeu oficialmente essa denominação com a lei municipal n.5.356, de 17 de abril de 2012.

O prof. Jorge Jim foi docente do Departamento de Zoologia da Unesp/Botucatu. Pesquisou os anfíbios anuros nos remanescentes de matas e entorno da região de Botucatu; foi coordenador e incentivador das pesquisas de fauna na área da Escola do Meio Ambiente, trabalhando principalmente com anfíbios. Orientou estagiários de graduação e pós-graduação em pesquisas na área da referida escola.

Sempre acreditou que a Escola do Meio Ambiente é a grande responsável pela preservação das nascentes e da represa com águas do ribeirão Lavapés, bem como dos remanescentes de floresta e cerrado encontrados nesta área.

Faleceu em 2011, deixando uma lacuna na área de pesquisa não só de Botucatu, mas do planeta como um todo (uma vez que tudo está interligado).

José Luis Chiaradia Gabriel

Coordenador das pesquisas de flora na área da Escola do Meio Ambiente do município de Botucatu 


\section{Metodologia}

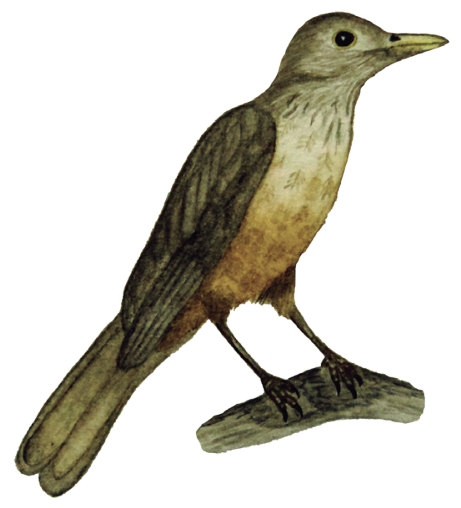

\section{Obtenção de dados dos animais silvestres que frequentam as matas e as trilhas da Escola do Meio Ambiente}

Há dez anos, a Escola do Meio Ambiente realiza trabalhos de investigação com o objetivo de descrever e conhecer as espécies animais que vivem em suas matas. Essas pesquisas são realizadas por estagiários, estudantes de cursos de graduação em Biologia, e são supervisionadas pela direção da escola com auxílio de docentes dos cursos de Biologia e Medicina Veterinária. São utilizadas diversas metodologias para a obtenção de dados sobre as espécies de aves, mamíferos, répteis, anfíbios, peixes e invertebrados que habitam a área da escola.

Além disso, funcionários e monitores também contribuem de forma espontânea, após a visualização de algum animal, ou após encontrar rastros ou vestígios, ninhos ou algum indício de que determinada espécie animal possa estar utilizando a área da escola como hábitat ou como passagem. Durante a realização de uma trilha, 
pode-se, eventualmente, observar e identificar alguma espécie animal, principalmente aves, por meio de sua visualização e/ou canto específico.

\section{Estratégias ou recursos didáticos}

Os estagiários, alunos dos cursos de Biologia, fazem o uso de baldes, colocados em áreas específicas da escola, para a identificação de espécies de pequeno porte, como mamíferos roedores (rato-silvestre), répteis, anfíbios e, principalmente, invertebrados. Para que seja possível determinar quais as espécies que deixam rastros e vestígios pelas trilhas e matas da escola durante a noite, utiliza-se uma câmara fotográfica específica, também conhecida como armadilha fotográfica, para fotos noturnas, em áreas da escola com possíveis alimentos para esses animais. Assim, são identificadas as espécies de mamíferos e aves com hábitos noturnos e que habitam as matas da escola.

\section{Metodologia da prática da educação ambiental} Atividades na trilha da Escola do Meio Ambiente

As crianças do primeiro ano do ensino fundamental I, ao visitarem a Escola do Meio Ambiente, participam da Trilha do Jequitibá, que trabalha a fauna e a flora da região de Botucatu. A trilha acontece no ecossistema onde a escola está localizada, a Floresta Irmãos Villas Bôas (floresta estacional semidecidual).

Durante a caminhada pela trilha, são trabalhados alguns aspectos de observação dos animais, como visualização de diferentes espécies de aves, rastros de mamíferos e indivíduos arbóreos representativos da flora de Botucatu. São estabelecidos diálogos com os alunos sobre as espécies animais que poderiam viver nas matas da 
Escola do Meio Ambiente. Após a atividade dessa trilha, as narrativas sobre os animais são contadas nas escolas pelos professores. Em seguida, fazem desenhos sobre a história contada, pois os alunos do primeiro ano do ensino fundamental I ainda estão em processo de alfabetização.

Cada aluno recebe um exemplar do material para levar para casa e mostrar à família. Dessa forma, a criança também atua como multiplicadora do conhecimento para a preservação das espécies animais locais e, consequentemente, desenvolve atitude positiva em relação ao meio ambiente.

\section{Proposta de atividades a partir da mudança conceitual}

A proposta de trabalho baseia-se na perspectiva da mudança conceitual, para que seja possível realizar a conexão da realidade e vivência da criança com conceitos e métodos científicos. As dezesseis histórias sobre as espécies animais que vivem na Escola do Meio Ambiente são motivadoras do trabalho e de sua relação com o conhecimento científico. As descrições e as ilustrações dos animais trabalham o conteúdo científico, ao tratar os aspectos morfológicos, dieta, nomes comuns, hábitats e distribuição das diferentes espécies animais.

É interessante realizar um trabalho de investigação prévia com os alunos, sendo, assim, possível entender o que os alunos sabem sobre os animais que vivem nas matas, a partir da sua realidade de vida, suas possíveis vivências e saberes ou experiências familiares e/ou individuais, sobre como imaginam como é uma floresta (hábitat de diferentes espécies de animais, aspectos da flora, entre outros fatores). A partir dos interesses (ou "carências"), estabelecer a relação da realidade com a experiência, com o empírico, conduzindo os alunos a partir de suas vivências práticas de acordo com conceitos e métodos da ciência (observação e visualização dos animais, de seus rastros, e de diálogos com os alunos).

Para isso, trabalha-se a percepção e a localização espacial, construindo um mapa geográfico e o espaço observado durante a trilha: 
o que é observado no alto das árvores (ninhos, aves), no chão (rastros, pegadas, restos de frutas que serviram de alimento para os animais que frequentam a matas, folhas secas que servem de hábitat para insetos), sons (cantos de aves, barulhos de insetos, vento), espécies de árvores e suas características morfológicas (altura, tipo de frutos, troncos como abrigo ou ninhos de animais). Assim, podem-se introduzir conceitos científicos sobre as diferentes espécies animais que vivem na Escola do Meio Ambiente e no município de Botucatu (Quem fez os ninhos? Quem dorme ou vive no ninho? Conceitos de preservação do ambiente, para não derrubar as árvores que abrigam os ninhos, preservar e respeitar o planeta Terra etc.).

Durante a trilha também é possível construir a percepção temporal dos acontecimentos, a exemplo da velocidade das passadas durante a trilha: se andam rápido ou devagar, determinando o ritmo da vivência a partir da própria vivência do momento, observar o que mudou e o que não mudou, e como mudou, ou seja, o que foi acontecendo e o que foi sendo modificado ao longo da trilha.

Todo o trabalho com os monitores nas trilhas e com os professores nas escolas, deve sempre procurar relacionar as experiências com os grupos em que as crianças vivem, por exemplo, se vivem em apartamentos: reforçar a ideia de observar (olhos), ouvir (ouvidos), sentir (mãos). No caso específico da Escola do Meio Ambiente, as crianças que realizam as trilhas, vivem, em sua maioria, em conjuntos habitacionais e também na zona rural. Percebe-se uma conexão importante desses alunos com o mundo virtual, sendo relevante o trabalho prévio de investigação e de desenvolvimento dos conceitos científicos pelo método da observação da natureza onde vivem.

O trabalho de metacognição, ou seja, de avaliar como aprenderam e detectar se o que aprenderam tem sentido para suas vidas, para que servirá em suas vidas, tem como objetivo alcançar um sentido mais do que um significado (científico). As crianças podem desenhar ou contar o que sabem a partir de como aprenderam a vivência na trilha. Os professores e alunos também podem desenvolver trabalhos de recorte-colagem, teatrinho, desenhos e brincadeiras. 
Exemplos dos aspectos do método utilizado são: observação e visualização de diferentes espécies de animais e diálogos com os alunos.

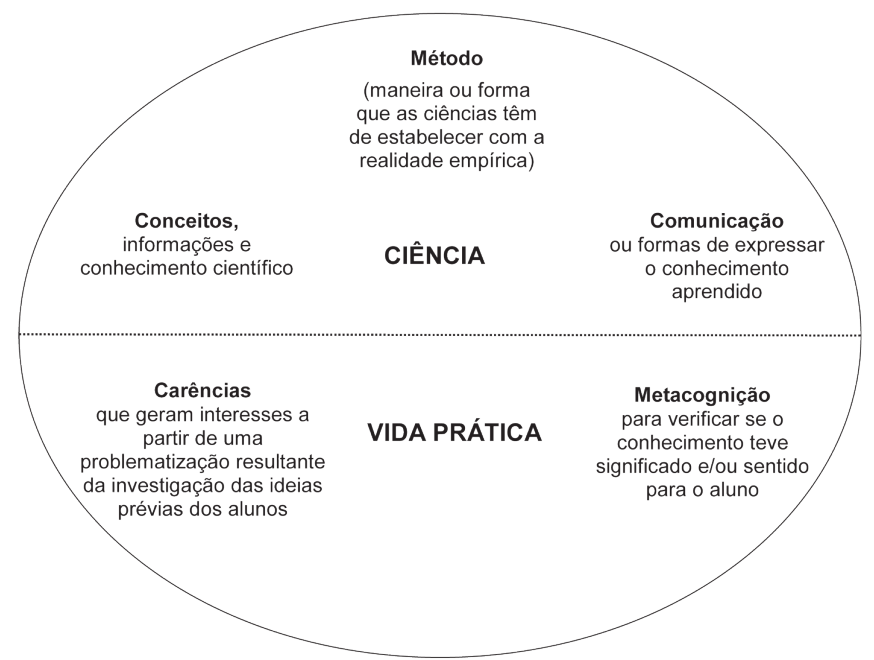

Quadro - Na vida prática, o conhecimento tem a função de orientar o agir (Adaptado de Rüsen, J. Razão histórica. Brasília: Editora da UnB, 2001, p.164.) 


\section{AlMA-DE-GATO \\ Piaya cayana (Linnaeus, 1766) (Squirrel Cuckoo)}

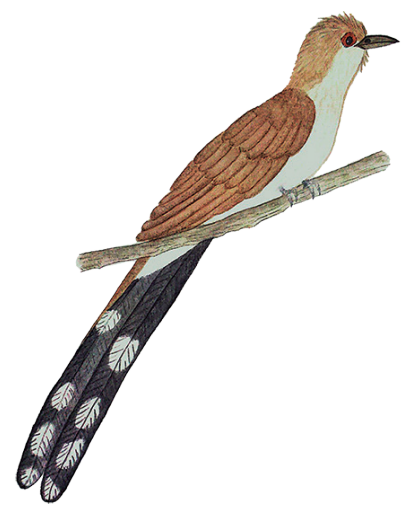

Nomes comuns: alma-perdida, atibaçu, pia, rabo-de-palha, chincoã, rabilonga, alma-de-caboclo, atingaú, atiaçu, maria-caraíba, tincoã.

Ave da ordem Cuculiformes, família Cuculidae.

Distribuição: neotrópicos - por todo o Brasil e América Latina (entre o México e a Argentina).

Morfologia e características gerais: plumagem de cor ferrugínea, pescoço, peito e abdômen com penas acinzentadas. Cauda longa, escura e com pontas coloridas. Bico amarelo-esverdeado, íris vermelha. Mede de 40 a $46 \mathrm{~cm}$ de comprimento (incluindo a cauda, que corresponde a dois terços do corpo). A fêmea bota de dois a seis ovos que são incubados por dezoito dias; os animais se reproduzem na primavera. Seu canto é semelhante ao gemido de um gato.

Hábitat: matas ciliares, matas secundárias, cerrado, capoeiras, campos com árvores, plantações, parques e cidades.

Dieta: frutinhas, insetos, lagartas, lagartixas, aranhas, besouros, abelhas e maribondos. 


\section{Alma-de-gato}

Em uma manhã de verão com céu azul, ar bem fresquinho, quando cheguei cedinho à Escola do Meio Ambiente, vi um pássaro diferente, com sua cauda aberta de pintas brancas, dando as boas-vindas ao dia e à floresta, ao pousar em um galho de jequitibá. E lembrei-me de trechos do poema "Gratuidade das aves e dos lírios", de Manoel de Barros, que quando menino gostava de observar os bichos na natureza:

Os pássaros conduzem o homem para o azul, para as águas, para as árvores e para o amor. [...] Por que não medir a relação de amor que os pássaros têm com as brisas da manhã? [...]. Queria descobrir por que os pássaros escolhem a amplidão para viver enquanto os homens escolhem ficar encerrados em suas paredes?

Nas matas da EMA, a gente pode viver a liberdade dos pássaros! Algo tão simples, verdadeiro presente da vida!

Na Escola do Meio Ambiente é assim, cada dia uma surpresa, são tantas as cores da natureza!

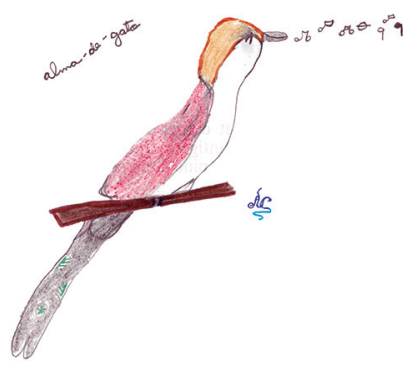




\section{Capivara \\ Hydrochoerus hydrochaeris (Linnaeus, 1766) (Capybara)}

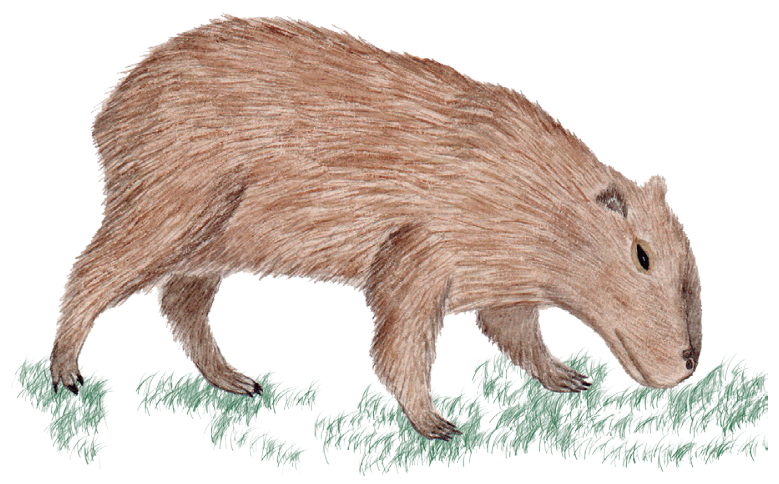

Nomes comuns: capinga, carpincho, capincho, capibara, porco d'água, paíba, capiguara, capiibá.

Mamífero da ordem Rodentia. É o maior roedor do mundo.

Distribuição: do Panamá, por toda a América do Sul, com exceção do Chile, até a bacia do rio Uruguai na Argentina. Habita todos os estados brasileiros.

Morfologia e características gerais: vivem em famílias de até vinte indivíduos, com um macho dominante e várias fêmeas. Excelentes nadadoras e mergulhadoras. Pesam de 30 a $100 \mathrm{~kg}$, podem viver até doze anos. A gestação é de 145 a 160 dias de um a oito filhotes, que mamam por dezesseis semanas. Coloração marrom-avermelhada. Possuem glândulas que secretam uma substância oleosa, utilizada para marcação de território.

Hábitat: cerrado, matas ciliares, manguezais e áreas alagadas.

Dieta: capim, gramíneas e vegetação aquática. 


\section{Vida em família}

Nos tempos de antigamente, o povo dizia que a capivara era bicho que "gostava de menino e não podia matar não", porque assustava os outros animais e, assim, tomava conta das crianças que gostavam de brincar no meio da floresta.

O nome científico da capivara é Hydrochoerus hydrochaeris, originário do grego e significa porco-d'água. Mas não faça confusão: as capivaras podem até parecer um porco, mas não têm focinho de porco não! São os maiores roedores do mundo! Gostam de ser como a gente, de viver em família.

Há muito tempo, as famílias das pessoas eram grandes, com pai, mãe e muitos filhos. As capivaras continuam sendo assim. Suas famílias têm mais de vinte indivíduos e são todos nadadores. Os filhotes adoram fazer competição em lagos e lagoas para ver quem nada mais e mergulha melhor! Às vezes, quando saem da água para dar uma voltinha nas florestas, uma capivarinha acaba se perdendo do bando e aí ela procura troncos de árvores sem uma parte da casca, que é o sinal de que está dentro do território da sua família.

Vamos brincar de procurar cascas de árvores pelo chão e troncos de árvores sem casca nas trilhas das florestas? Quem sabe a gente encontra uma família de capivaras passeando nas matas da EMA?

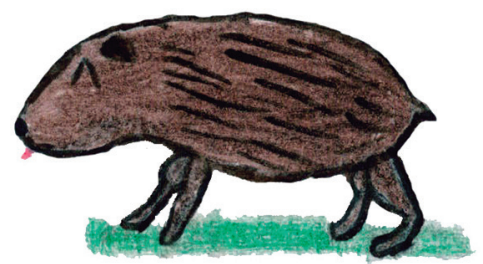




\section{CuícA \\ Gracilinanus agilis (Burmeister, 1854) (Agile gracile opossum)}

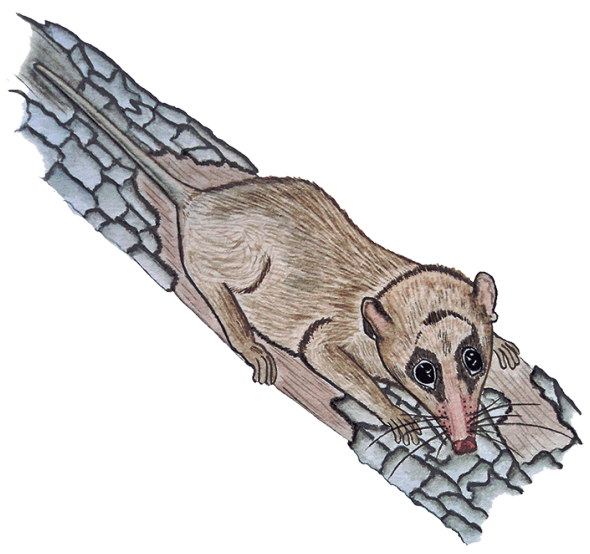

Nomes comuns: cuíca, catita, guaiquica.

Marsupial da família Didelphidae.

Distribuição no Brasil: do estado do Piauí até o Rio Grande do Sul.

Morfologia e características gerais: coloração dorsal variando de marrom-avermelhado a marrom-acinzentado com um anel de pelos escuros ao redor dos olhos. O corpo mede de 70 a 109 mm e a cauda de 95 a $162 \mathrm{~mm}$.

Hábitat: vive nas proximidades dos cursos d'água, é noturna, arborícola e constrói ninhos em árvores. Tem hábitos solitários.

Dieta: insetívora, carnívora e frugívora. 


\section{Cuíca}

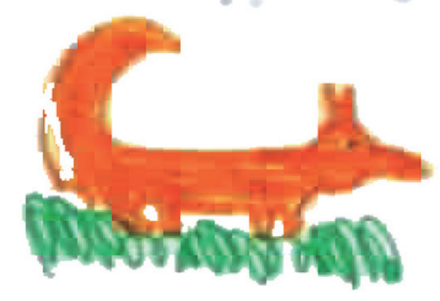

Um dia desses recebi uma notícia que me deixou muito feliz! Soube que nasceu a Cuíca, uma bezerrinha toda branca com manchinhas marrons, no sítio da minha amiguinha Fernanda. E que foi ela quem escolheu esse nome! Soube também que ela está adorando acompanhar os primeiros passos da Cuíca.

Cuíca também é o nome de um animalzinho com pelagem marrom. Os pelos em volta dos olhos formam anéis que parecem óculos. A cuíca gosta de comer banana e mamão, além de alguns insetos e até mesmo rãs e lagartos! Essa cuíca de que estou falando também é um mamífero, pois mama quando é filhote, assim como a Cuíca bezerrinha. Ela pertence à mesma família dos gambás, só que não tem um cheirinho ruim como eles. Os cientistas descobriram a cuíca há muito tempo, em 1854, e deram um nome bem difícil a ela: Gracilinanus agilis, mas que a gente simplificou para cuíca mesmo.

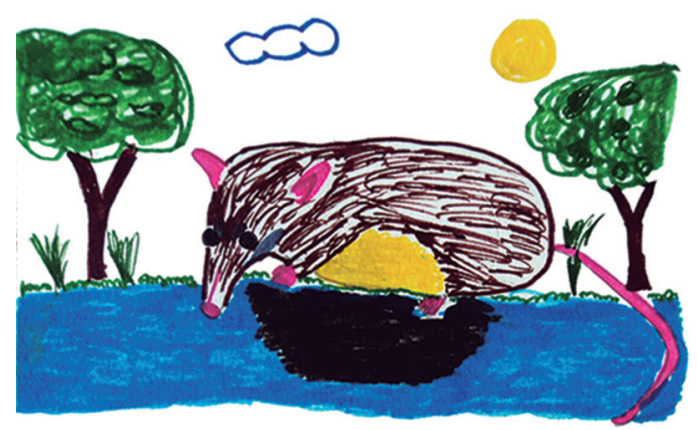


Gosto muito de filhotinhos. Voltando à bezerrinha Cuíca, ela ainda está mamando e, aos pouquinhos vai começar a comer capim, só que, pra isso, a mãe dela vai ter que dar uma grande ajuda. Já a cuíca silvestre gosta de passear à noite nas florestas e fazer ninhos no topo das árvores, bem diferente da bezerrinha Cuíca, que passa o dia mamando e depois dorme bem quentinha ao lado da mãe. Minha amiguinha, Fernanda, vai cuidar bem da bezerrinha Cuíca dela e nós vamos cuidar bem das matas para preservar as cuícas do Brasil! Viva a Cuíca! Vivam as cuícas! 


\section{GAMBÁ \\ Didelphis albiventris (Lund, 1840) (White-eared opossum)}

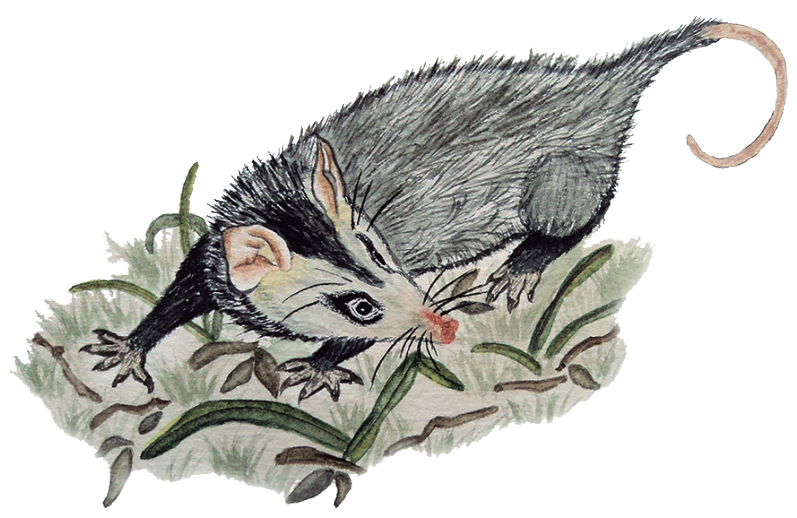

Nomes comuns: gambá-de-orelha-branca, timbú, mucura, sariguê, saruê, micurê, cassaco. Nos estados de São Paulo, Paraná e Santa Catarina, é conhecido como raposa ou raposinha.

Maior mamífero marsupial do Brasil. Pertence à família Didelphidae.

Distribuição no Brasil: por todo o país. Principalmente nas regiões de cerrado, caatinga e no Pantanal.

Morfologia e características gerais: coloração cinza, com pelos em duas camadas, a inferior tem pelos claros ou brancos e a camada superior de pelos pretos grossos. Orelhas claras com faixa preta na face que inclui os olhos. Corpo de até $70 \mathrm{~cm}$. Cauda comprida e preênsil coberta de pele grossa e nua com pelos apenas na base. Hábito solitário e noturno, ninhadas de sete a onze filhotes. Apresenta glândula sob a cauda que produz substância de odor característico, secretada como mecanismo de defesa ou durante o cio para atrair o parceiro. Hábitos crepusculares ou noturnos. 
Hábitat: matas, florestas, cidades. Arborícolas e terrestres. Habilidade para subir em árvores.

Dieta: frutos, sementes, ovos, pequenos vertebrados, insetos e outros invertebrados.

\section{Gambá Raposinho}

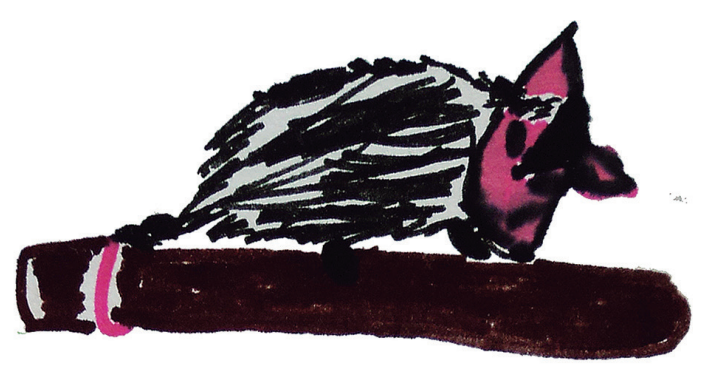

O gambá Raposinho gosta de viajar e conhecer novos lugares. Nasceu no estado do Paraná, onde seu nome já causou muitas confusões. Isso porque, nos estados do Sul do Brasil e também no estado de São Paulo, as pessoas têm mania de dizer que o gambá é uma raposa. Nada disso. Gambá é um marsupial e a raposa é um carnívoro! Assim, todas as vezes que o gambá Raposinho conhece alguém, tem logo que explicar: o nome gambá tem origem na língua tupi-guarani, guaamba, que significa "mama oca”, referência ao marsúpio, ou seja, a bolsa onde estão as mamas e onde os filhotes vivem durante seu crescimento. E ainda diz: meus pais queriam me dar um nome carinhoso e também fazer uma homenagem à raposa, animal que vive nas florestas e um bicho muito respeitado. Raposinho conheceu matas e florestas muito bonitas, algumas um pouco destruídas pelo homem e outras bem preservadas.

Hoje, Raposinho vive na Floresta Irmãos Villas Bôas, na Escola do Meio Ambiente, em Botucatu, estado de São Paulo, onde gosta de observar, no final da tarde, as crianças passeando pelas trilhas quando visitam a escola. Ele tem vários sonhos. Um deles é que todas as crianças aprendam que gambá é gambá, raposa é raposa e que 
ajudem a cuidar da natureza, para que futuros Raposinhos possam viajar e contar suas histórias por aí.

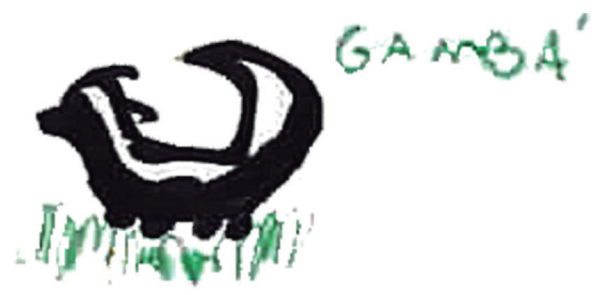




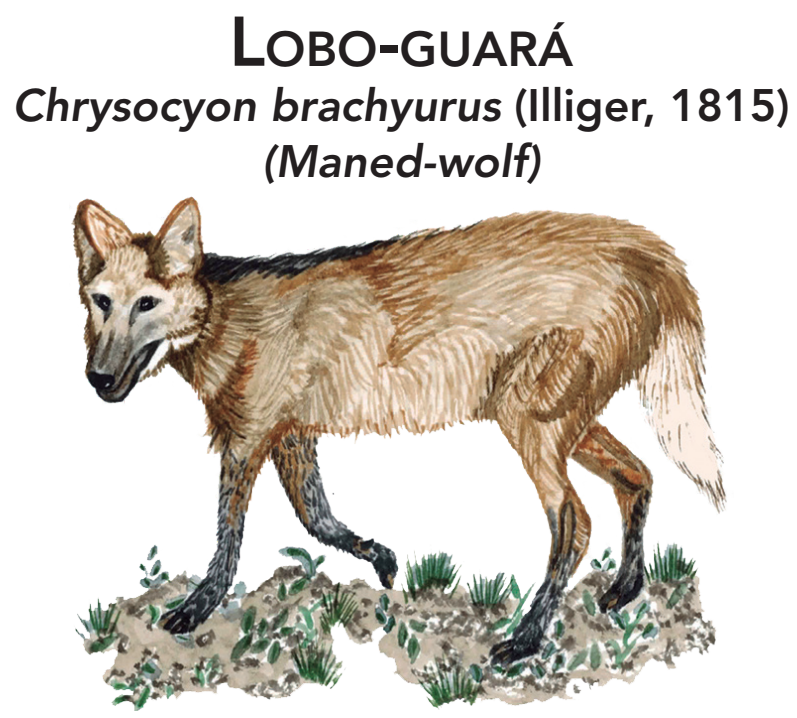

Nomes comuns: guará, aguará, aguaraçu, lobo-vermelho, lobo-de-crina, caxito, jaguaperi, avará.

Mamífero da ordem Carnívora, família Canidae.

Distribuição: nativo da América do Sul.

Morfologia e características gerais: medem de 95 a $132 \mathrm{~cm}$ (cabeça e corpo) e cauda de 28 a $49 \mathrm{~cm}$. Pesam de 20 a 26 kg. Coloração vermelho-amarelada. As extremidades das patas são escuras. $\mathrm{O}$ pescoço e os tufos da cauda são brancos. Orelhas grandes e eretas e crânio alongado. Gestação de 62 a 66 dias, de duas a quatro crias, que mamam até 15 semanas. Hábitos solitários, noturnos e crepusculares. Maior canídeo nativo da América do Sul.

Hábitat: cerrado, pântanos, pradarias. Ameaçado de extinção no Brasil.

Dieta: são onívoros. Alimentam-se de frutas, principalmente da lobeira (Solanum lycocarpum), conhecida como a fruta do lobo, presente no cerrado. Pequenos a médios vertebrados, como roedores, aves e répteis, além de insetos e diversos vegetais. 


\section{O bicho dourado do cerrado}

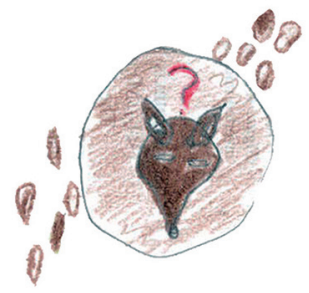

Pegadas e mais pegadas pelas trilhas da mata e do Bosque Educativo Frei Afonso da Escola do Meio Ambiente nos trazem uma bela notícia! Descobrimos que um bicho do cerrado, o maior canídeo da América do Sul, com pegadas que mostram a união da almofadinha da pata entre o terceiro e o quarto dedos, anda por lá. São animais que nascem com pelagem escura e aos poucos adquirem tons de vermelho e as pernas só se tornam longas quando adultos. Seu alimento predileto é a fruta da lobeira, também conhecida como fruta do lobo. São solitários e gostam de passear durante a noite. Você já descobriu que bicho é esse?

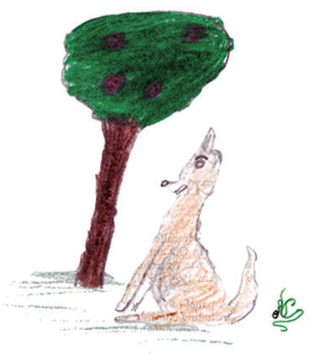

Isso mesmo! É o lobo-guará ou lobo vermelho. Uma bênção da natureza que mostra a união dos animais, das plantas e da gente, para que possamos entender o significado da vida! 


\section{ONÇA-PARDA \\ Puma concolor (Linnaeus, 1771) \\ (Cougar)}

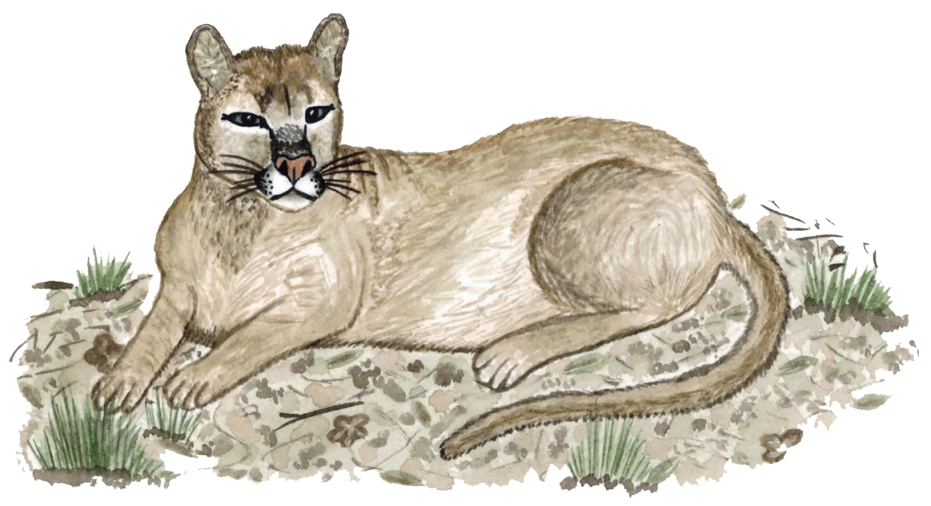

Nomes comuns: suçuarana, leão-baio, puma, leão-da-montanha, leão-americano, onça-vermelha, jaguaruna, iauaruna, guaçuarã, guaçuarana, guaçurã.

Mamífero da ordem Carnívora, família Felidae.

Distribuição: nativo das Américas - América do Sul, Central e do Norte. No Brasil, é encontrada na caatinga, cerrado, floresta amazônica, floresta atlântica, campos e no Pantanal.

Morfologia e características gerais: maior espécie do gênero Felis, coloração avermelhada ou acinzentada, com tons de ferrugem. A cabeça é pequena, corpo alongado, pescoço e cauda compridos. Orelhas pequenas, curtas e arredondadas. Machos medem (cabeça e corpo) entre 105 a $196 \mathrm{~cm}$, com cauda de 66 a $78 \mathrm{~cm}$ e pesam de 67 a $103 \mathrm{~kg}$. As fêmeas medem (cabeça e corpo) entre 96 a $151 \mathrm{~cm}$, com cauda de 53 a $82 \mathrm{~cm}$ e pesam de 36 a $60 \mathrm{~kg}$. Os animais menores vivem em florestas e os maiores em regiões montanhosas. Gestação de 90 a 96 dias, de um a seis filhotes, que mamam por doze semanas. 
Os filhotes apresentam manchas pretas nos pelos que desaparecem até os seis meses. São muito ágeis, com grande poder de salto. A onça-parda é o animal símbolo do município de Botucatu (SP).

Hábitat: florestas, montanhas, pântanos, planícies.

Dieta: mamíferos, como capivaras, veados, tatus, quatis e catetos, além de outros vertebrados de médio porte.

\section{Suçuarana}

A onça-parda, também conhecida como suçuarana, é o animal símbolo do município de Botucatu. É um mamífero carnívoro e vive por todo o continente americano, desde o norte do Canadá até o sul da Argentina e do Chile.

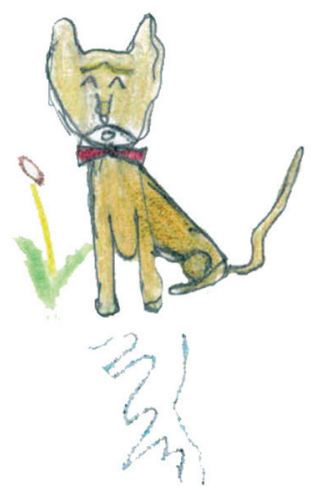

Aí você pode se perguntar: por que então foi escolhida como animal símbolo de Botucatu? Bem, é o maior felino do estado de São Paulo e o segundo maior do Brasil. Vive em todas as regiões do nosso país, mas está ameaçada de extinção, pois seu hábitat está sendo transformado em plantações, pastagens e até mesmo em cidades. Assim, a suçuarana perde sua casa, sua fonte de alimentos e acaba chegando cada vez mais perto do homem, procurando criações de animais para se alimentar.

A Escola do Meio Ambiente tem uma área de mata preservada, paraíso para os animais viverem em paz. A suçuarana passeia ao 
entardecer e à noite pela EMA, subindo em árvores e deixando suas pegadas para a gente saber que ela passa por lá e divide a mata com outros animais.

E não precisa ficar com medo não! As suçuaranas são solitárias, tímidas e dificilmente atacam o homem quando se sentem protegidas em seus hábitats. 


\section{OURIÇO-CACHEIRO \\ Sphiggurus villosus (F. Cuvier, 1823) (Orange-spined hairy dwarf porcupine)}

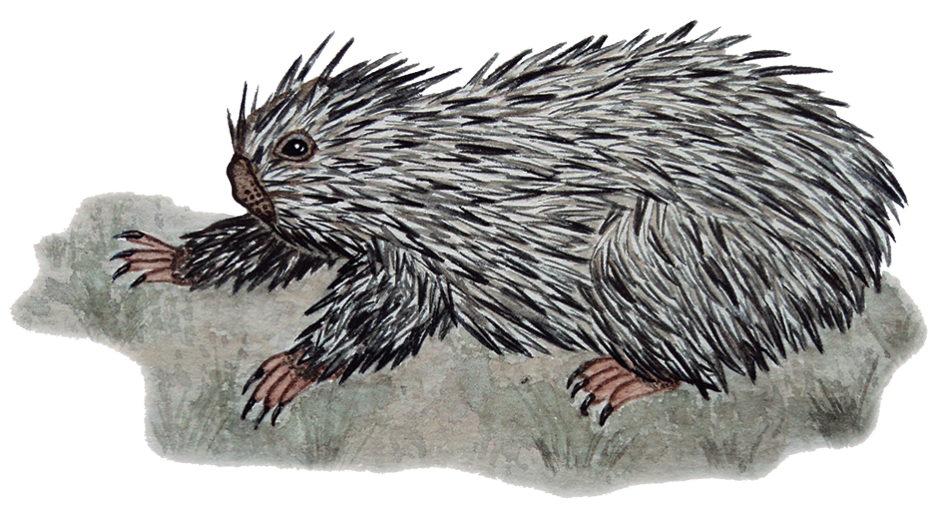

Nomes comuns: ouriço, ouriço-caixeiro.

Roedor da família Erethizontidae.

Distribuição no Brasil: Mata Atlântica - estados de Minas Gerais, Rio de Janeiro até o Rio Grande do Sul.

Morfologia e características gerais: dorso amarelo-escuro. Pelos em forma de espinhos de até $40 \mathrm{~mm}$ de comprimento, de cor amarela, negro na cauda e ponta clara. Pescoço, peito e ventre recobertos de pelos. Cauda preênsil e unhas fortes. Pesam em média $1 \mathrm{~kg}$. Longevidade média de doze anos. Hábito noturno, filhotes são encontrados nos ocos de árvores.

Hábitat: florestas. Arborícolas, principalmente no topo das árvores.

Dieta: folhas, flores, brotos, sementes e frutas. 


\section{O passeio do ouriço-cacheiro}

Certa manhã, quando chegava à Escola do Meio Ambiente, vi um bichinho andando pelo pomar. Parei para olhar e, para minha surpresa, era um bebê ouriço-cacheiro. Você conhece os ouriços-cacheiros? Eles mamam quando são filhotes e são cheios de pelos na forma de espinhos, parecem mesmo um porco-espinho! Ele andava devagar, como se estivesse aproveitando os primeiros raios de sol para fazer um passeio, depois da chuvarada da noite.

Andava tranquilo, espreitando as árvores e os sons dos pássaros. Afinal de contas, ainda era cedinho, hora certa de procurar os amigos e brincar de encontrar frutinhas pelo caminho, para depois levar para casa e fazer a sobremesa com seus irmãos. Nas florestas, os ocos das árvores velhas servem de casa para os ouriços-cacheiros, onde passam o dia todo dormindo. Eles saem para procurar sementes, frutos e folhas durante a noite ou no nascer do sol. Acho que tive uma baita sorte de chegar cedinho à escola e encontrar o ouricinho à procura de comida. Por isso, agora sei que a floresta da EMA abriga famílias de ouriços-cacheiros, que eles vivem e passeiam por lá e que comem as frutinhas que caem no chão. A floresta é casa de muitos bichos. Onde tem vida, tem alegria e o mais importante e mais bonito é que a gente pode sonhar e aprender a conviver com todos os seres vivos da natureza em paz.

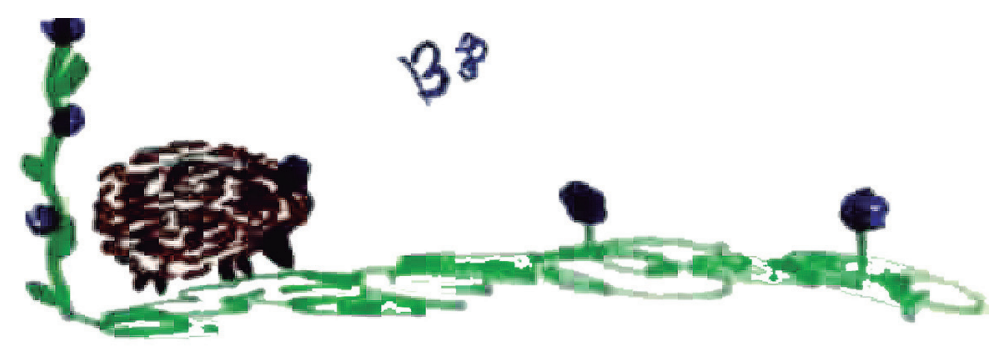




\section{Periquitão-maracanã Aratinga leucophthalma (Statius Muller, 1776) (White-eyed Parakeet)}

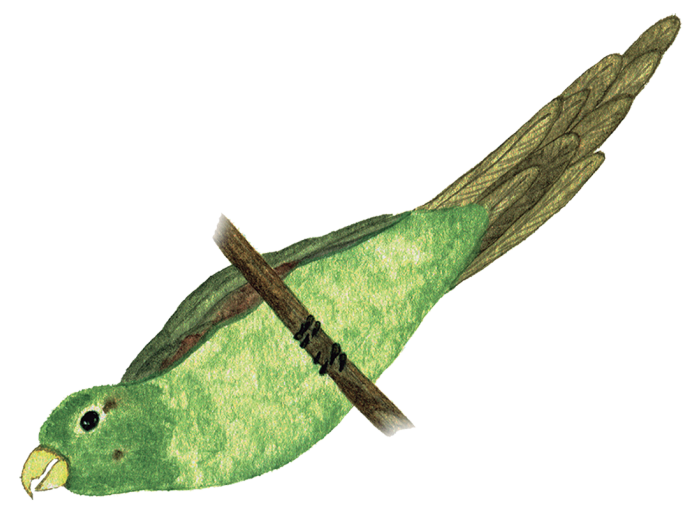

Nomes comuns: maritaca, aratinga-de-bando, araguaí, araguari, arauaí, jandaia-verde, giguilim.

Ave da ordem Psittaciformes, família Psittacidae.

Distribuição: em quase todo o Brasil e em grande parte da América do Sul.

Morfologia e características gerais: papagaio de tamanho médio, corpo com coloração predominantemente verde, com penas vermelhas nas faces laterais da cabeça, pescoço e asas. A região ao redor dos olhos é esbranquiçada e sem penas. Mede aproximadamente $30 \mathrm{~cm}$, pesa entre 140 a 170 gramas. Pode viver até trinta anos, voa em bandos de cinco a quarenta indivíduos.

Dieta: sementes, brotos, flores e folhas, atraídos por árvores frutíferas (mangueiras, goiabeiras, laranjeiras, mamoeiros, bananeiras), milharais e cafezais, insetos. 


\section{As cores do Brasil}

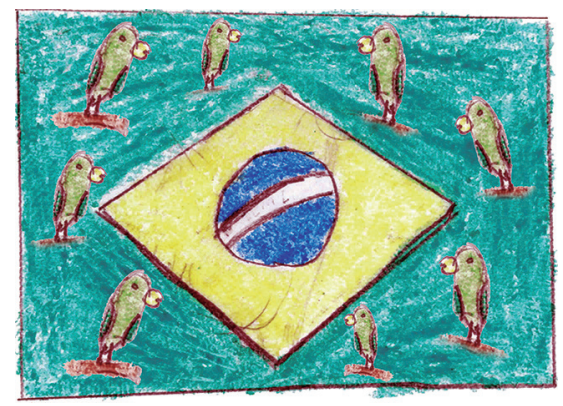

Voos verdes no céu azul com poucas nuvens, em um dia de sol forte, pelas verdes matas da Escola do Meio Ambiente. O periquitão-maracanã é assim, está entre as aves mais inteligentes do mundo e voa em bandos, cantando alto, bem alto, para dizer "bom dia" ou "bom fim de tarde".

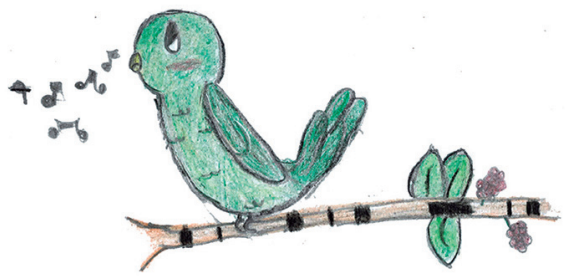

No estado de São Paulo, é conhecido como maritaca. O seu nome científico, Aratinga, é como os indígenas chamam essa ave, e leucophthalma vem do grego e significa olho (ophthalmos) branco (leukos). É tão bonito observar o voo dessas aves, com suas penas verdes pelo corpo e penas brancas ao redor dos olhos, quando combinado com o céu azul de poucas nuvens, em um dia de sol, atraídas pelo verde das árvores frutíferas da EMA.

Todas essas cores e voos são os mesmos das cores da bandeira do Brasil! Você já imaginou as maritacas em nossa bandeira? 


\section{Quero-Quero \\ Vanellus chilensis (Molina, 1782) \\ (Southern lapwing)}

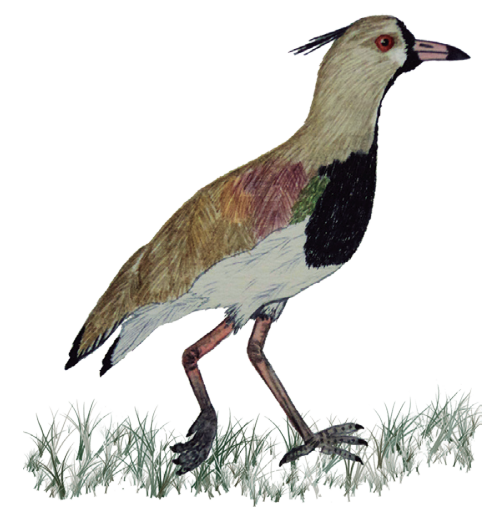

Nomes comuns: terém-terém, espanta-boiada, téu-téu, tero-tero, uirateonteõ, teteu, gaivota-preta, guirá-teú, chiqueira.

Ave da ordem Charadriiformes, família Charadriidae.

Distribuição: por toda a América do Sul, em todo o Brasil e alguns países da América Central.

Morfologia e características gerais: medem de 32 a 38 cm de comprimento e pesam em média 260 gramas. A fêmea bota de um a quatro ovos. $\mathrm{O}$ adulto possui esporão no ângulo da asa e um topete na nuca, formado por um penacho cinza ou preto. A plumagem é cinza com tons de marrom ou azul-escuro, do topo da cabeça até o dorso e também nas laterais do pescoço. Por dentro, as asas são brancas. Plumagem negra com branco na testa e no pescoço e área preta no peito. Íris vermelha. Bico vermelho com a ponta preta. Patas avermelhadas. Voos curtos.

Hábitat: campos, mangues, áreas costeiras, ao redor de lagos e rios, brejos, praias arenosas, várzeas úmidas, vegetação rasteira, pastagem, áreas urbanas. 
Dieta: insetos, pequenos peixes e crustáceos, invertebrados aquáticos e terrestres.

\section{Quero-quero}

Vamos brincar com as palavras? Quero-quero é uma derivação onomatopaica de seu grito. O que é isso? O que é onomatopeia? Onomatopeia é quando a gente imita um som. Assim, o canto do quero-quero é uma onomatopeia: quero-quero, quero-quero, quero-quero...

O quero-quero é uma ave que protege o seu território; quando acha que um campo de futebol é sua área de vigilância, às vezes pode atrapalhar um jogo inteiro, porque imagina que os jogadores estão invadindo seu território; aí, parte para o ataque, mesmo que de uma forma meio desajeitada, pois a bola de futebol pode ser uma ameaça. Vanellus, seu gênero, vem do latim, que significa ventoinha - por causa do movimento desajeitado de bater as asas. O quero-quero é a ave símbolo do estado do Rio Grande do Sul e no folclore brasileiro há uma quadrinha que diz assim:

Quero-quero vai voando

e os esporões vai batendo

Quero-quero quando grita

Alguma coisa está vendo

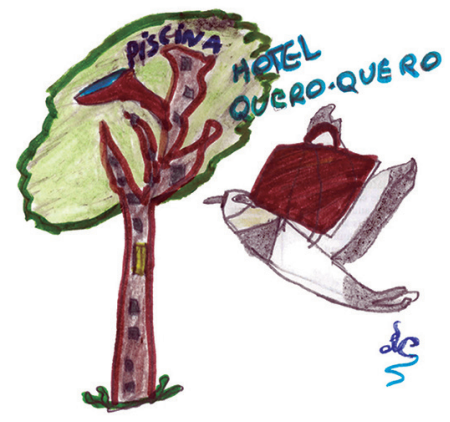


Vamos brincar de onomatopeia? Quais outros nomes de pássaros são onomatopeias? Vamos passear nas trilhas da Escola do Meio Ambiente para procurar aves com sons que podemos imitar? 


\section{RATO-DO-MATO \\ Oligoryzomys nigripes (Olfers, 1818) \\ (Black-Footed pygmy rice rat)}

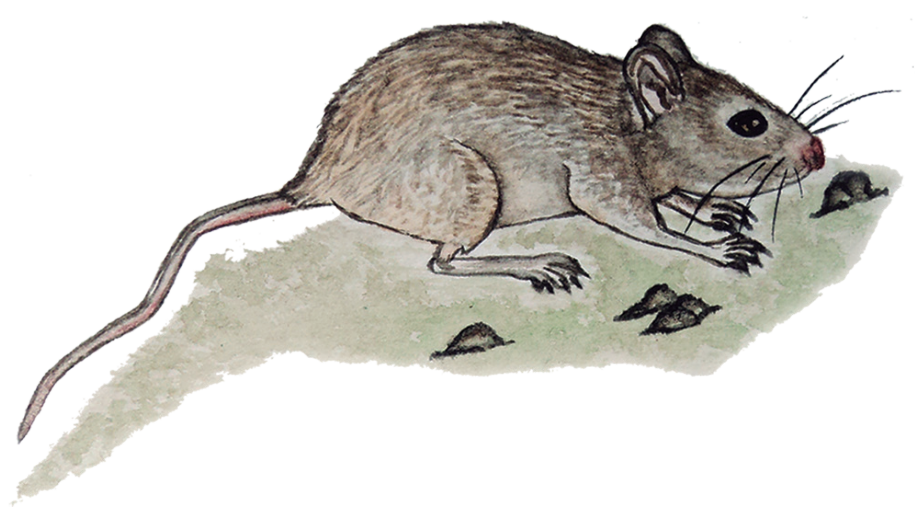

Oligoryzomys nigripes (Olfers, 1818) hoje inclui Oligoryzomys eliurus (Wagner, 1845), seguindo a tendência atual de considerar essas formas sinônimas.

Nomes comuns: ratinho-silvestre, camundongo-do-mato, rato- catingueiro.

Roedor da família Cricetidae.

Distribuição no Brasil: Mata Atlântica e porção sul do cerrado (Brasil central e sudoeste).

Morfologia e características gerais: o adulto pesa até 30 gramas. Orelhas compridas, corpo com pelos amarelo-escuros e ventre esbranquiçado. São terrestres e bons escaladores.

Hábitat: campos, clareiras, plantações de arroz e matas.

Dieta: frugívoro, granívoro e insetívoro. 


\section{A noite dos ratinhos silvestres}

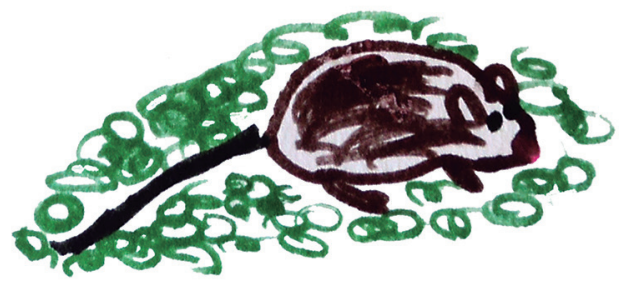

Nas noites estreladas de lua cheia, nas matas da Escola do Meio Ambiente, os ratinhos silvestres saem para dar uma voltinha. Eles têm olhos grandes e a cauda é maior que o corpo! Os passeios da noite são datas especiais para esses bichinhos, pois são dias de festa, quando as famílias se juntam para comemorar a lua cheia, que ilumina as árvores para que eles possam subir, saltar e andar em todas as direções. A alegria é tanta, que trazem para o luar todas as sementinhas e frutinhas que guardaram nos buracos dos troncos das árvores para compartilhar com a família e com os amigos. São criaturas tão pequenas que, se a gente passear pela floresta à noite, nem vai perceber a festança. Mas ninguém precisa ficar triste com isso não, porque podemos sonhar e imaginar todos os ratinhos de olhos esbugalhados saltitando de um lado pro outro e, assim, saber que as matas abrigam muitos animais, que eles gostam de celebrar a vida e o que eles mais querem é que a gente possa comemorar cada noite estrelada, de lua cheia, com paz e alegria entre todos os seres!

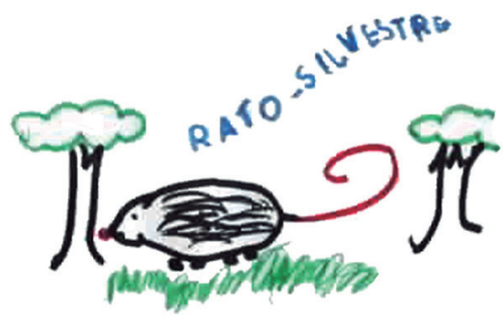




\section{SABIÁ-LARANJEIRA Turdus rufiventris (Vieillot, 1818) (Rufous-bellied thrush)}

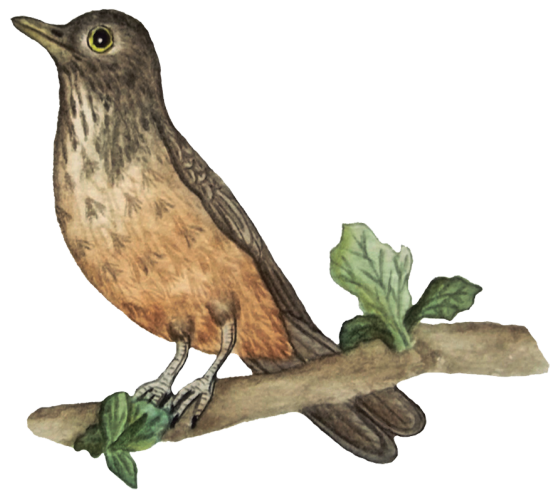

Nomes comuns: sabiá, sabiá-de-barriga-vermelha, sabiá-piranga, sabiá-laranja.

Ave da ordem Passeriformes, família Turdidae.

Distribuição no Brasil: por todo o país, com exceção da bacia amazônica.

Morfologia e características gerais: ventre alaranjado, asas e cabeça cinza-esverdeados. A pele ao redor dos olhos é amarelada. Mede cerca de $25 \mathrm{~cm}$.

Hábitat: florestas abertas, campos, lavouras e nas cidades.

Dieta: insetos, aranhas, sementes, frutas maduras, minhocas e larvas. 


\section{O sabiá-laranjeira e a passarada}

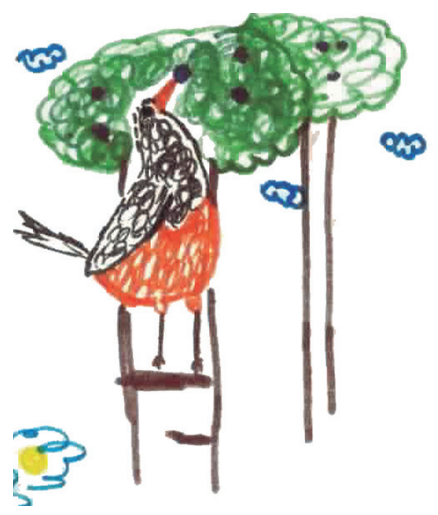

A Escola do Meio Ambiente é casa de muitos pássaros que adoram fazer festas. $\mathrm{O}$ meu avô gostava de contar histórias sobre a vida dos sabiás. Dizia que são aves com certidão de nascimento, porque, na primavera, sempre fazem o ninho na mesma árvore, ano após ano. E falava assim: "Com sabiá não se brinca, menina!".

A mãe sabiá fica muito brava quando seu filhotinho resolve testar suas asas e cai do ninho. Ela não fica brava com ele, mas não para de piar pra avisar toda a floresta que precisa de ajuda, chamando o pai sabiá pra procurar o filhote pelo caminho e voar de volta ao ninho. Os filhotes de sabiá querem aprender logo a voar para ir às festas de casamento do joão-de-barro e da joaninha-de-barro, ouvir as bandas de sabiás, tocar violino e ver toda a passarada dançar. As festas de casamento quase sempre acontecem no finalzinho do inverno, quando os ipês-amarelos florescem. Todos os pássaros são convidados: alma-de-gato, tesourinha, beija-flor, coleirinho, tiziu, tico-tico, andorinhas, canários, corruíras, bem-te-vis e muitos outros. O sabiá-laranjeira é a ave símbolo do Brasil e o canto de cada sabiá é único. Por isso, fazem tanto sucesso nas festas da floresta! 


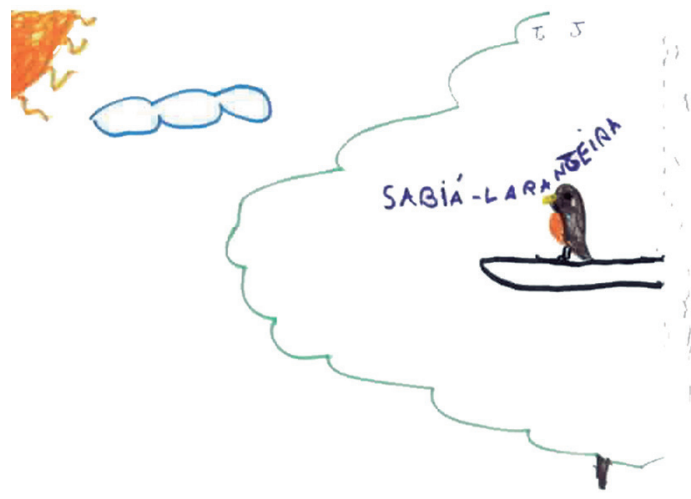




\section{SARACURA \\ Aramides saracura (Spix, 1825) \\ (Slaty-breasted wood rail)}

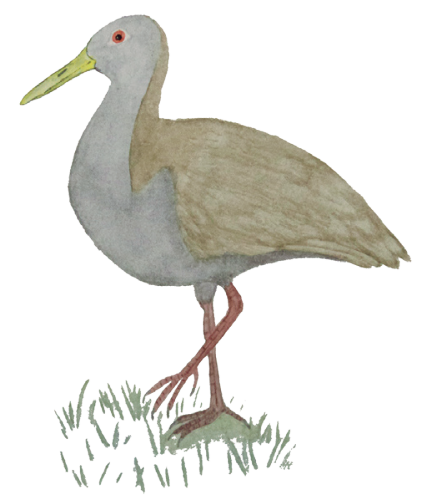

Nomes comuns: saracura, saracura-do-brejo, siricoia.

Ave da ordem Gruiformes, família Rallidae.

Distribuição no Brasil: sul e sudeste do país.

Morfologia e características gerais: ventre, cabeça e pescoço azul-acinzentados, patas longas de cor vermelha. Olhos de coloração avermelhada e bicos esverdeados. Mede $34 \mathrm{~cm}$.

Hábitat: florestas, áreas alagadiças e pantanosas. Hábitos terrestres, correm pela vegetação em vez de voar.

Dieta: desovas de pererecas, capim, brotos de milho, insetos e larvas.

\section{O esconde-esconde da Saracura}

As saracuras são aves de pernas longas e finas, bico verde e olhos vermelhos que correm pelo mato em vez de voar. Elas adoram as visitas das crianças nas trilhas da Escola do Meio Ambiente. Ficam 
nos arredores da represa com águas do ribeirão Lavapés, pois o lanche predileto delas são os ovinhos das pererecas, colocados em plantas submersas. Têm um jeito todo especial de espiar os nossos passeios. Às vezes, a gente

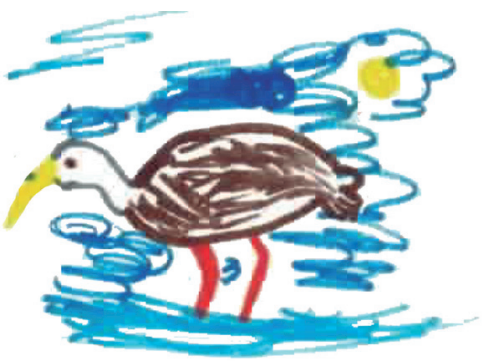
nem imagina que estão por perto! Elas gostam de juntar os amigos e amigas saracuras para brincar de esconde-esconde na vegetação. Por isso, parecem que estão sempre correndo da gente. Que nada! Todos os caminhos das trilhas da EMA servem para a brincadeira das saracuras e pra gente saber se elas estão por lá, basta prestar atenção e preparar os ouvidos para escutar seu canto forte e estridente! A mata, com toda sua riqueza de árvores, flores, frutos, sementes, terra, ar, água e muitos, muitos bichos, serve de quintal para as brincadeiras das saracuras. Serve também pra pensar que sempre podemos brincar com as cores da natureza. Eé isso que enriquece a vida no nosso planeta!

\section{SARACURA}

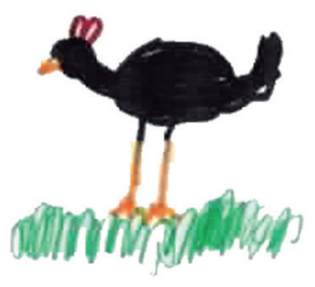




\section{Serelepe \\ Sciurus ingrami (Thomas, 1901) \\ (Brazilian squirrel)}

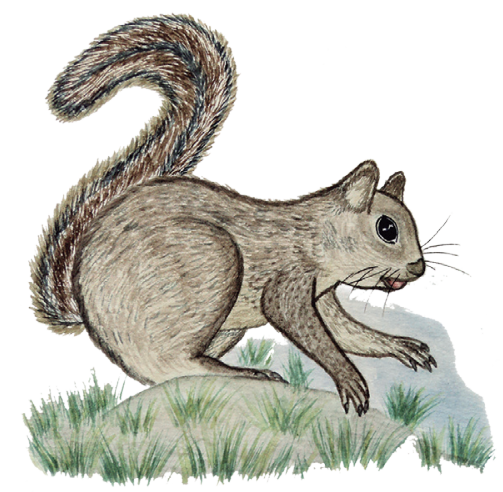

Nomes comuns: serelepe, esquilo, caxinguelê.

Roedor da família Sciuridae.

Distribuição no Brasil: do sul do estado da Bahia até o Rio Grande do Sul.

Morfologia e características gerais: cauda longa, maior que o corpo, recurvada sobre o dorso. Pelagem longa, espessa e macia, coloração marrom-esverdeada, mais escura na nuca e no dorso. Pescoço e ventre com pelagem esbranquiçada.

Hábitat: arborícolas, ágeis, deslocam-se ao longo dos troncos das árvores e pulam de galho em galho com facilidade. Vivem nas matas e bosques.

Dieta: folhas, flores e sementes ricas em óleos, frutos de palmeira, sementes de araucária, frutos do araçá. 


\section{Serelepe}

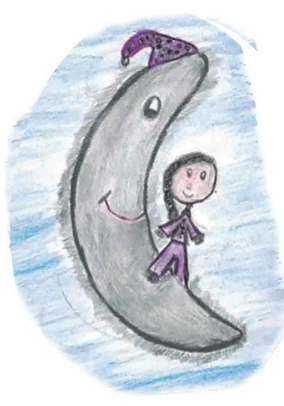

$\mathrm{Na}$ minha infância, gostava muito de ouvir músicas. Naquela época, os discos eram chamados de LPs, feitos de um plástico preto, conhecido como vinil. Antigamente, não existiam $\mathrm{CDs}$ nem MP3.

Um deles, em especial, era sobre os bichos; a música que mais gostava era a do esquilinho. Um dia desses, estava passeando pela Escola do Meio Ambiente e descobri que famílias de esquilos vivem por lá. Pois bem, comecei a vasculhar na memória para lembrar o que eu sabia sobre esses bichinhos. Comecei uma tarefa de tentar encontrar a música do esquilo. Fui visitar a casa dos meus pais, que guardam coisas antigas. Adorei a aventura! Daquelas de procurar coisas dentro do baú, cheias de poeira e tantas histórias! Achei o disco "Bichos, bichinhos e bichões", com capa preta e desenhos coloridos de vários bichos. Uma parte da tarefa estava cumprida. Na minha casa, em Botucatu, tem uma radiola, feita para tocar discos de vinil. Assim, começava a segunda parte da aventura. Vamos cantar juntos?

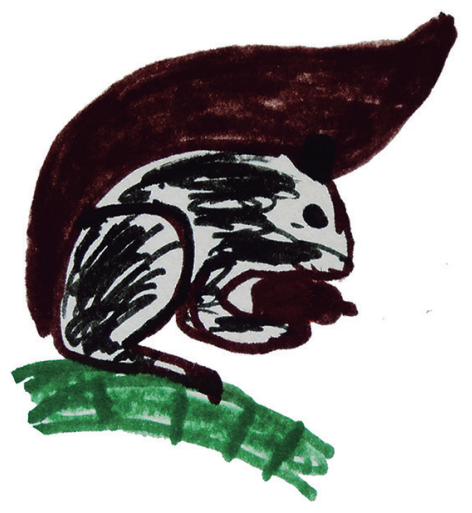




\section{Serelepe}

(Rita Amaral/Vera Helena)

O esquilo brasileiro, serelepe ou caxinguelê.

É pequeno e tem rabo comprido, se assusta com tudo o que vê. Constrói sua casa dentro do tronco vazio, onde abriga a filharada do vento, da chuva e do frio.

É um bichinho roedor, que está sempre a trabalhar, pulando de galho em galho, não para pra descansar.

Ele tem muitos amigos e não faz mal a ninguém. Na floresta é conhecido como um bichinho de bem.

Várias famílias de serelepes vivem nas árvores da mata da Escola do Meio Ambiente, que faz bem a tanta gente! 


\section{TAMANDUÁ-BANDEIRA Myrmecophaga tridactyla (Linnaeus, 1758) (Giant anteater)}

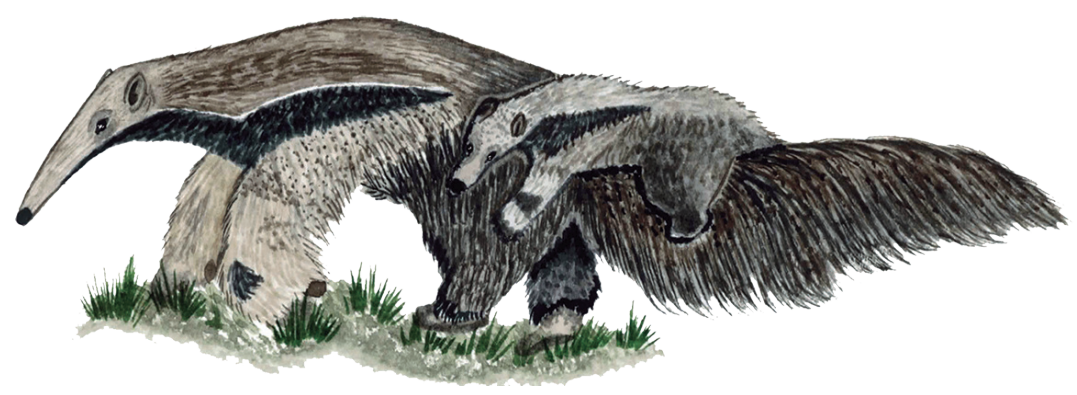

Nomes comuns: tamanduá, papa-formigas, tamanuá, cumbiri, cupiguara, tamanduá-açu, tamanduá-cavalo, iurumi, jurumirim, tamanduatê.

Mamífero da ordem Xenarthra, família Myrmecophagidae.

Distribuição: todo o Brasil.

Morfologia e características gerais: corpo e cabeça medem entre 1 a 1,2 metro e a cauda mede de 65 a 90 centímetros. Pesam entre 18 a $39 \mathrm{~kg}$. Coloração marrom-acinzentada, com listas diagonais pretas e brancas. Focinho cilíndrico. Possuem língua comprida (aproximadamente 60 centímetros), bem desenvolvida, que ajuda na alimentação. Não têm dentes. São ativos durante o dia e à noite. Gestação de 190 dias de apenas um filhote, que pesa entre 1 a $2 \mathrm{~kg}$ ao nascer, abre os olhos com seis dias de vida e mama até dois meses e meio. $\mathrm{O}$ filhote é carregado nas costas da mãe até quase um ano.

Hábitat: florestas úmidas, áreas remanescentes de cerrado, pântanos, campos e pastagens.

Dieta: são frugívoros e insetívoros (formigas, térmitas e larvas de besouros). 


\section{Creche de tamanduás}

Os tamanduás filhotes andam de carona nas costas de suas mães até 1 ano de idade, quando estão prontos para viver sozinhos. São bichos importantes na natureza, pois controlam a quantidade de formigas e cupins. Hoje em dia, com o desmatamento, queimadas e a destruição de seus hábitats, acontecem muitos casos de atropelamentos e os filhotes órfãos acabam indo para os zoológicos. Para cuidar deles, são criadas verdadeiras creches e, para ajudar na alimentação, eles recebem uma mistura de insetos, frutas e iogurte. Vamos cantar uma música para conhecer o tamanduá-bandeira?

\section{Que Bicho É Esse?}

(do musical Urubububu, de Elizabeth Woolley)

Que bichoé esse

Que é primo do bicho-preguiça

E daquele outro

Que mora no buraco

Tatu!

É solitário

E ele nasceu no cerrado

Tem a cauda grande

Em forma de bandeira

Um focinho longo, snif

Pra comer formigas

Nham nham

Que bicho é esse?

Ele é primo do bicho-preguiça

E do tatu

Tatu

Alguém já adivinhou

que bicho é esse? 
Ta tama tamanduá-bandeira

Ta tama tamanduá-bandeira.

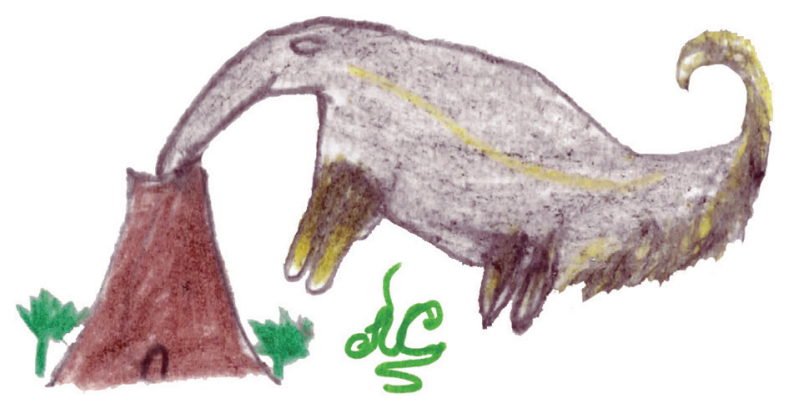




\section{TATU-GALINHA \\ Dasypus novemcinctus (Linnaeus, 1758) \\ (Long-nosed armadillo) (Nine-banded armadillo)}

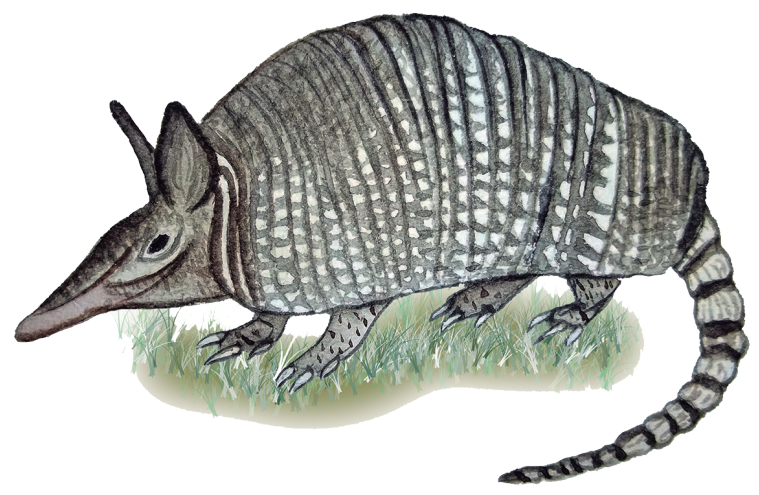

Nomes comuns: tatu-verdadeiro, tatu-veado, tatu-de-folha, tatuetê.

Mamífero da ordem Xenarthra, família Dasypodidae.

Distribuição: desde o sudeste dos Estados Unidos da América até o norte da Argentina e no Brasil.

Morfologia e características gerais: o corpo mede de 240 a $573 \mathrm{~mm}$ e a cauda de 125 a $483 \mathrm{~mm}$. Ausência de pelos na porção dorsal e presença de raros pelos no ventre. As patas da frente têm quatro dedos e as patas de trás têm cinco dedos. Cavam buracos que podem chegar a 3,5 metros de profundidade e 7,5 metros de comprimento, para fazer os ninhos com folhas e grama. Hábitos noturnos, principalmente no verão, mas podem ser observados ao longo do dia. Gestação de 120 dias, com ninhadas de quatro filhotes, sempre do mesmo sexo. Mamam até os quatro meses.

Hábitat: cerrado, campos, pampas e florestas. 
Dieta: onívoros, insetos (principalmente besouros e formigas), pequenos répteis e anfíbios.

\section{Irmãos gêmeos}

Os tatus são os mais primitivos dos mamíferos xenartros, que é a mesma ordem dos tamanduás e bichos-preguiça, mas possuem algo bem diferente desses parentes um pouco distantes. Além de fazerem tocas pelas florestas e campos onde vivem, eles têm muitos irmãos gêmeos e primos por toda a América do Sul, América Central e até em alguns estados do sul dos Estados Unidos da América. A ciência nos ensinou que isso é resultado da poliembriogenia, que nada mais é que uma explicação para dizer que quando a mãe tatu fica grávida, são gerados quatro filhotes e todos do mesmo sexo. Ou nascem quatro irmãos ou quatro irmãs gêmeas. Com isso, as famílias crescem e buscam diferentes lugares para viver, viajando pelo continente americano.

Os tatus viajam cavando a terra, fazendo tocas que servem de abrigo para outros bichos e assim conhecem novas florestas e novos caminhos.

A Escola do Meio Ambiente, em Botucatu, tem uma trilha dedicada aos tatus e suas tocas. Que tal um passeio pela Floresta Irmãos Villas Bôas, na EMA, para conhecer as estradas construídas pelos tatus?

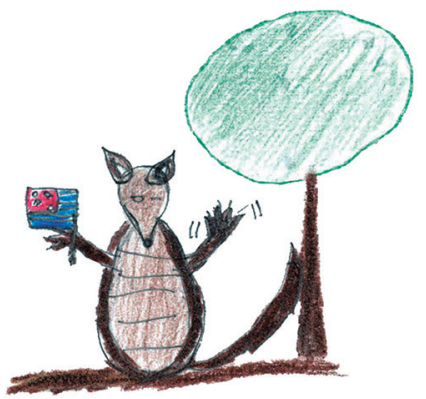




\section{TUCANO \\ Ramphastos toco (Statius Muller, 1776) \\ (Toco toucan)}

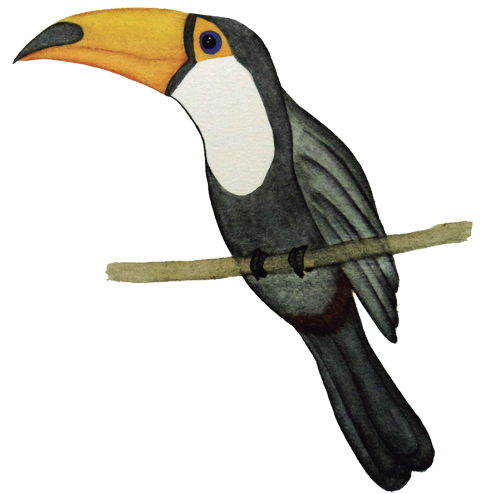

Nomes comuns: tucano, tucanuçu, tucanaçu, tucano-boi.

Ave da ordem Piciformes, família Ramphastidae.

Distribuição no Brasil: extensa nas florestas do território brasileiro, típicos da floresta amazônica.

Morfologia e características gerais: pesa em média 500 gramas e tem entre 40 a $60 \mathrm{~cm}$ de comprimento, possui 14 vértebras cervicais. Sem dimorfismo sexual. Bicos longos e coloridos com língua filamentosa, fímbrias laterais, com aparência de uma pena. Plumagem negra e avermelhada embaixo da cauda. Asas curtas e cauda relativamente longa. Vivem em pares ou grupos.

Hábitat: florestas, sertões secos da caatinga e vegetação baixa do cerrado. Ninhos em cavidades de tronco de árvores.

Dieta: pequenas frutas, frutos de goiabeira, figueira, embaúba e palmito. Pequenos invertebrados (aranhas, grilos, cupins). Ovos e filhotes de passarinhos. 


\section{Vida de tucano}

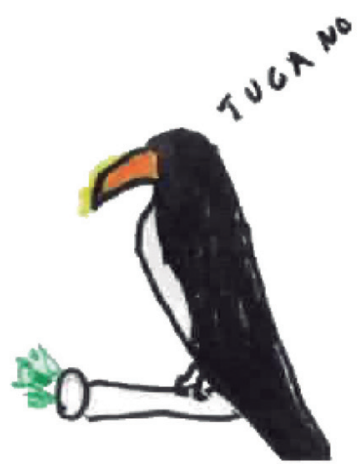

Na mata da Escola do Meio Ambiente vivem vários tucanos. São aves lindas, o bico todo colorido de alaranjado nem parece de verdade! Quando nascem, não têm penas, mas têm uma almofadinha na perna, para que possam ficar protegidos dos materiais ásperos dos ninhos. A natureza é sábia mesmo! Os casais de tucanos se revezam para chocar os ovos e alimentar os filhotes, nos ninhos que fazem em ocos de árvores. Às vezes, os casais usam, emprestados, os ninhos dos pica-paus para colocar de dois a quatro ovinhos, que irão incubar por pouco mais de duas semanas. Depois, devolvem os ninhos para as famílias dos pica-paus. Quanta amizade! Com um mês e meio, os filhotes estão prontos para deixar o ninho. São brincalhões, gostam de voar pelas florestas e também por algumas cidades. Em Botucatu, de vez em quando somos agraciados com tucanos voando de um lado para outro. É uma maravilha observar esta ave tão linda, tão colorida perto da gente!

Dormem empoleirados; para isso, colocam o bico sobre as costas e a cauda sobre as costas e a cabeça. Será que isso é jeito de tucano dormir? Parece um gatinho enrolado em cima de uma almofada! Infelizmente, por serem tão bonitos, muitas vezes são capturados para o tráfico de animais, para ser vendidos em lojas. Por isso, no futuro, podem entrar em extinção.

Já imaginaram o nosso céu, nossas matas e cidades sem o voo dos tucanos? Sem as brincadeiras alegres dos bandos de filhotes? Que 
tal a gente ajudar os tucanos a serem livres na natureza para que possam continuar encantando nossas vidas com tão rara beleza?

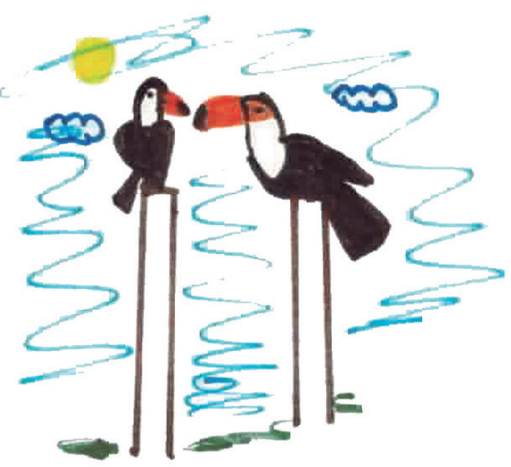




\section{Fotos DE ALGUNS ANIMAIS QUE FREQUENTAM AS MATAS E AS TRILHAS DA EMA}

As imagens foram obtidas por observações durante passeios pela EMA e por uso de câmera (ou armadilha) fotográfica com infravermelho colocada em diferentes locais da escola no período noturno, sendo que aos finais de semana a câmera era colocada às $18 \mathrm{~h}$ de sexta-feira e retirada às $8 \mathrm{~h}$ de segunda-feira.

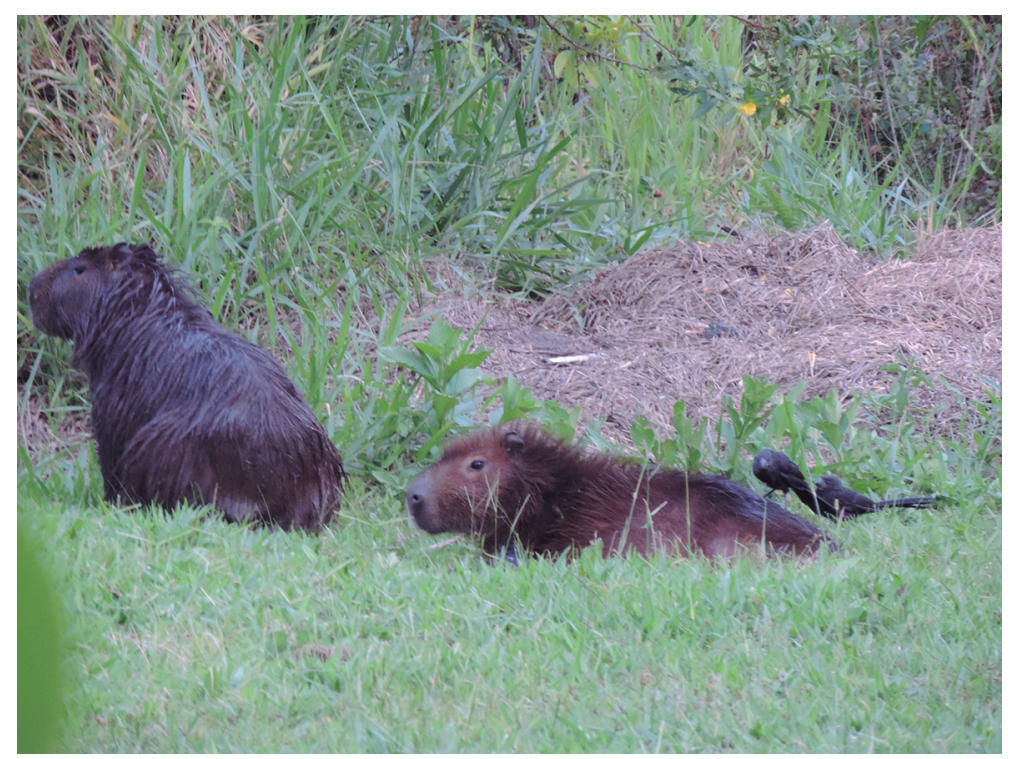

Capivaras na área da horta pedagógica. 
74 ELIZABETH M. DOS SANTOS SCHMIDT • ELIANA MARIA NICOLINI GABRIEL

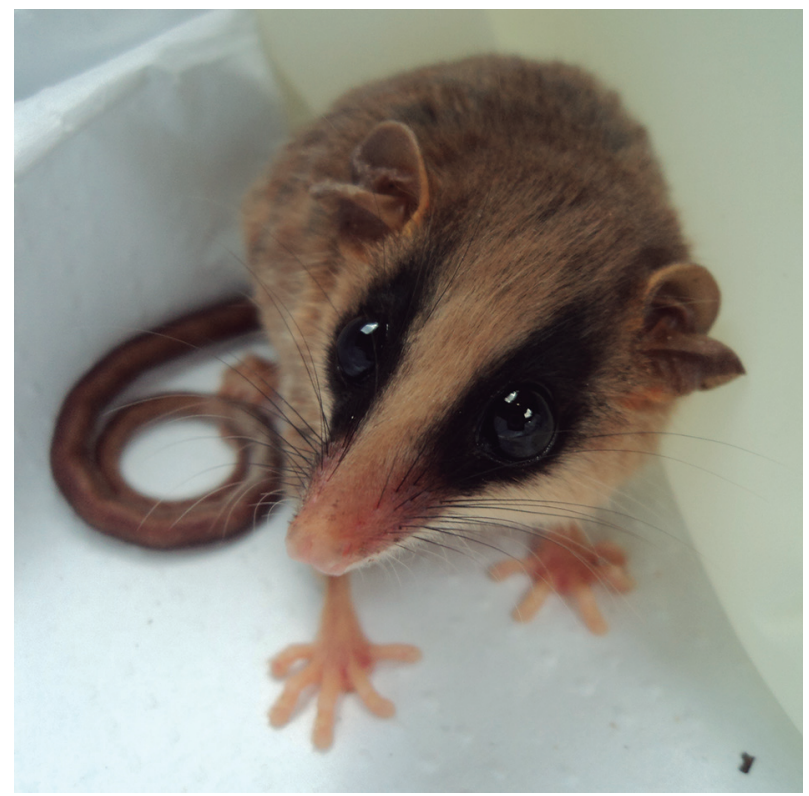

Cuíca encontrada na pesquisa com armadilha do tipo pitfall.

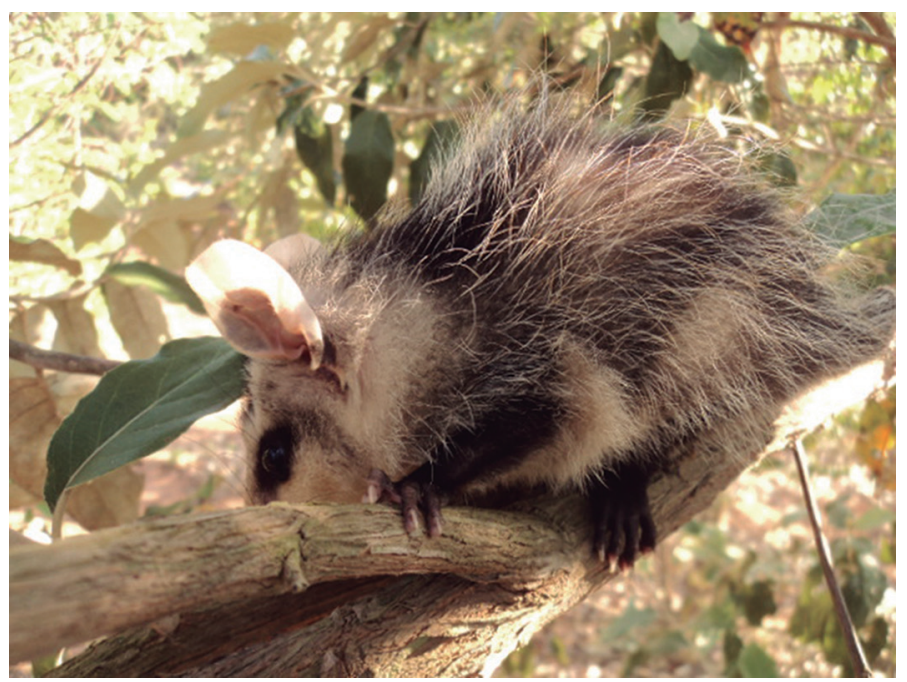

Gambá fotografado em cima de uma árvore próxima ao Bosque Frei Afonso. 


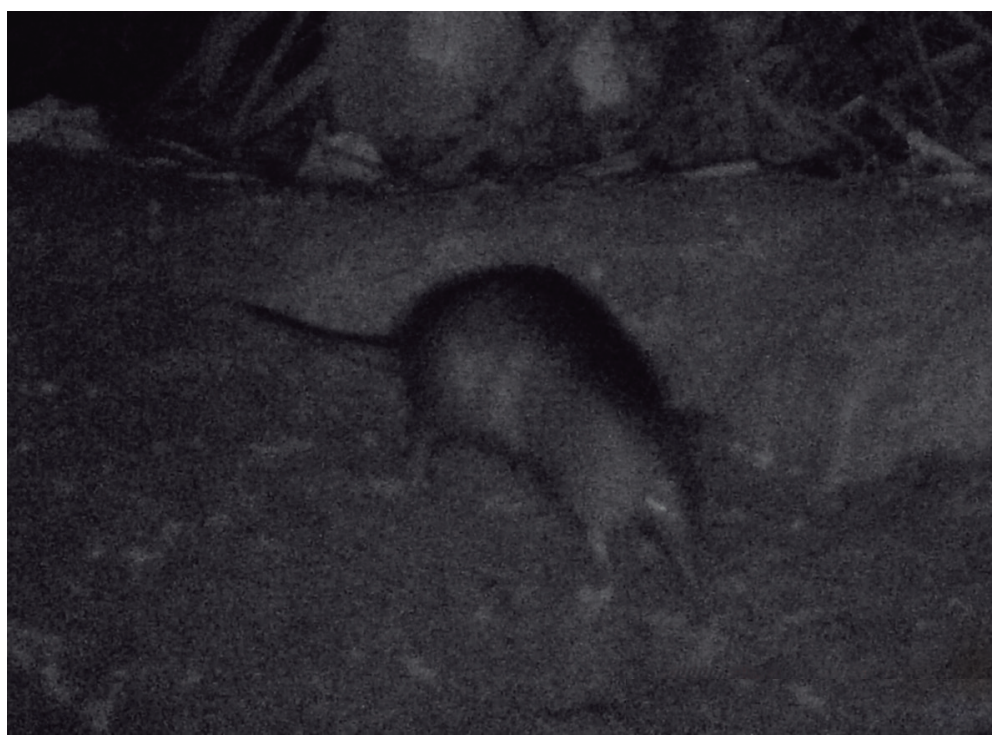

Tatu-galinha observado na área de compostagem em fotografia noturna.

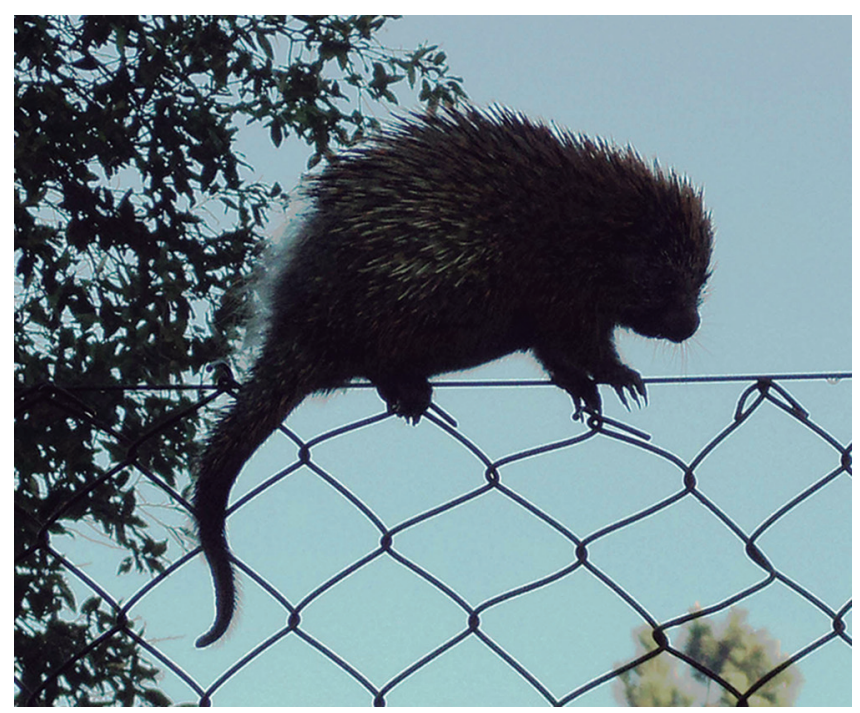

Ouriço-cacheiro observado na cerca da horta. 
76 ELIZABETH M. DOS SANTOS SCHMIDT • ELIANA MARIA NICOLINI GABRIEL

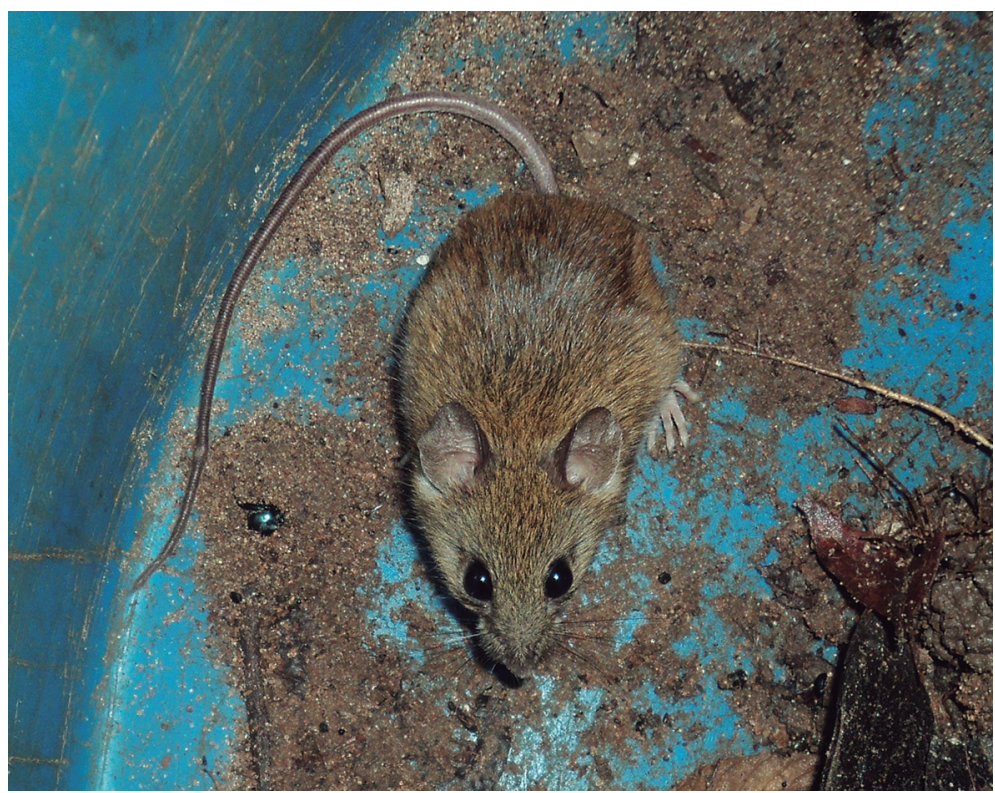

Rato-do-mato recuperado de baldes na armadilha do tipo pitfall.

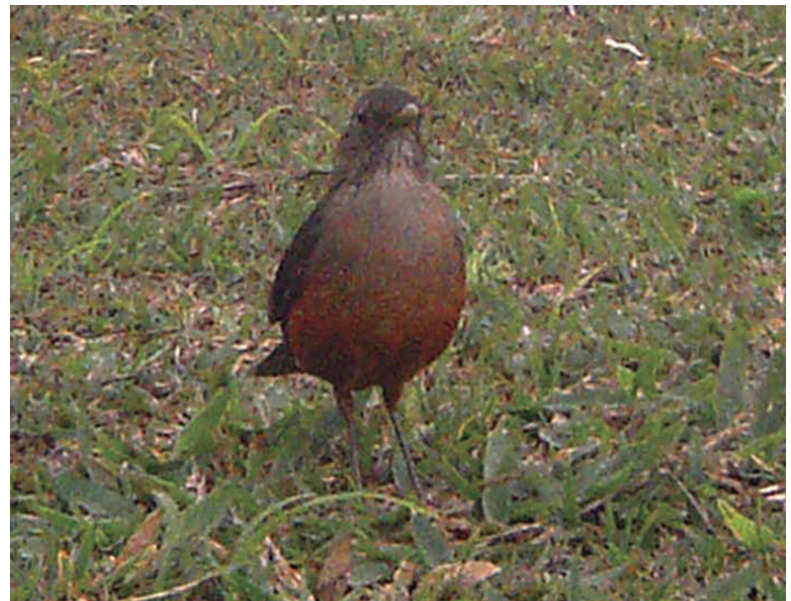

Sabiá-laranjeira no parquinho ao lado da represa. 


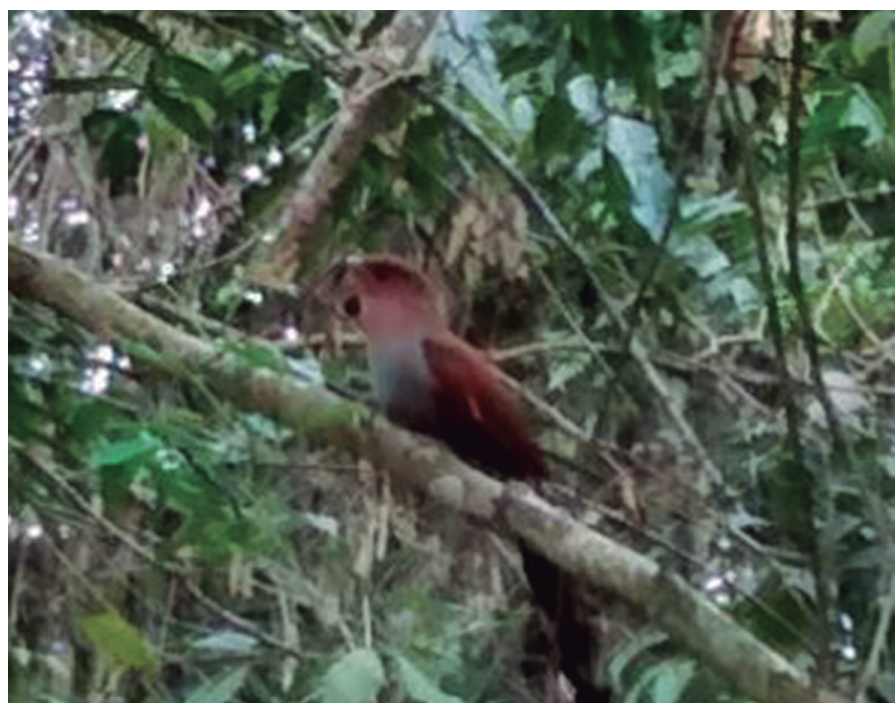

Alma-de-gato observado no alto de uma árvore.

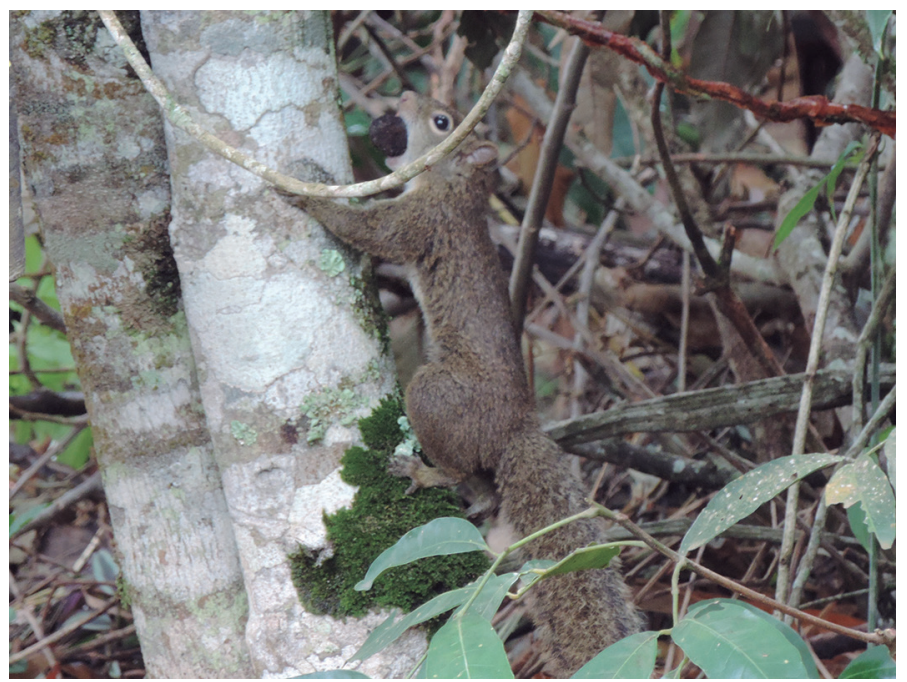

Serelepe encontrado na horta pedagógica. 
78 ELIZABETH M. DOS SANTOS SCHMIDT • ELIANA MARIA NICOLINI GABRIEL

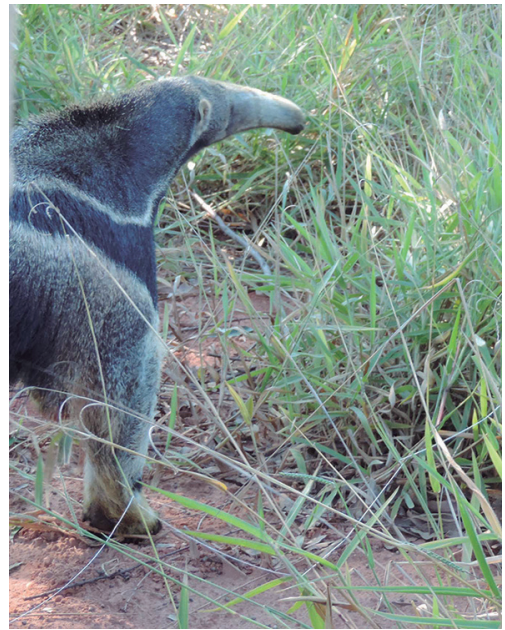

Tamanduá-bandeira observado na área de cerrado.

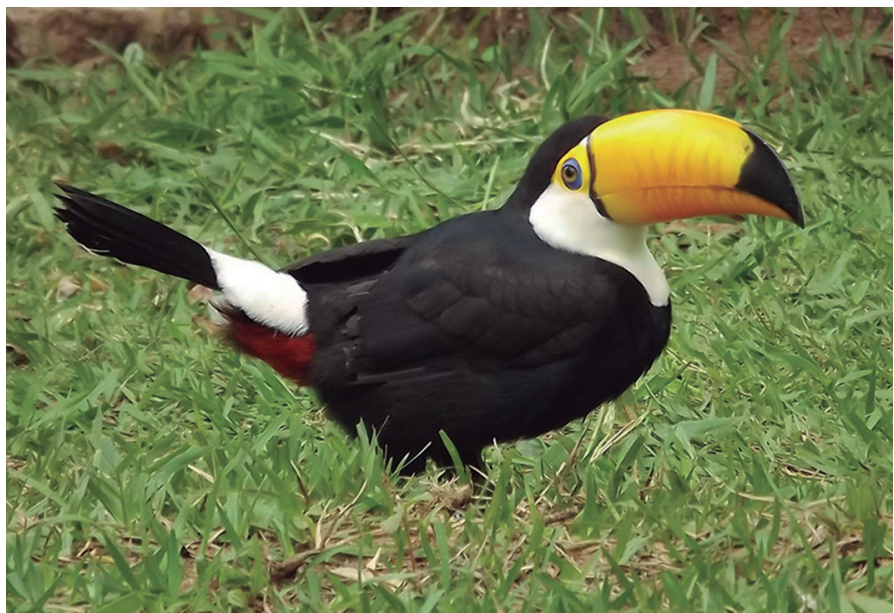

Tucano no jardim da escola. 


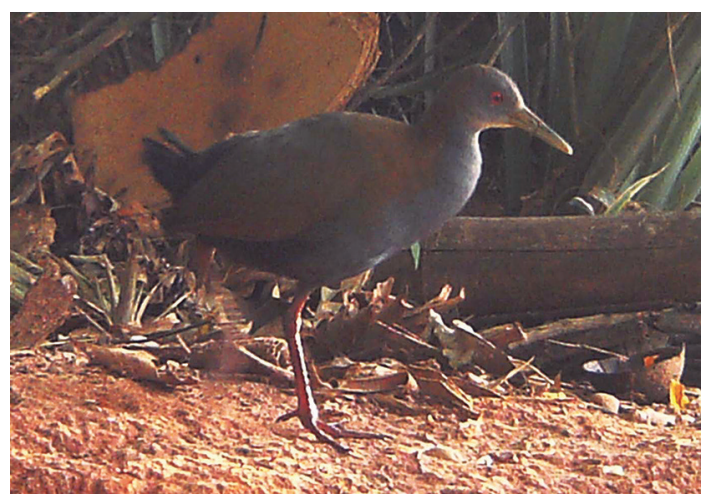

Saracura observada próximo à Represa Prof. Jorge Jim.

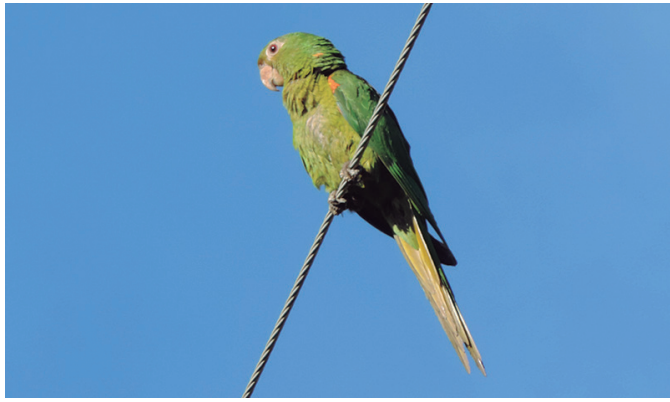

Periquitão-maracanã na fiação paralela à Floresta Irmãos Villas Bôas.

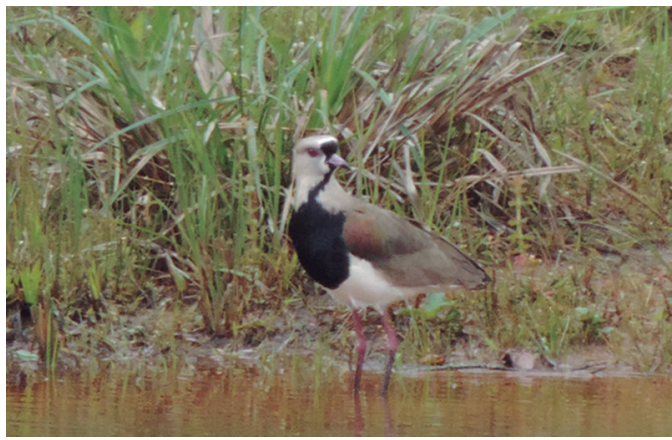

Quero-quero na borda da represa.Rastro de lobo-guará observado na estrada ao lado da horta. 
80 ELIZABETH M. DOS SANTOS SCHMIDT • ELIANA MARIA NICOLINI GABRIEL

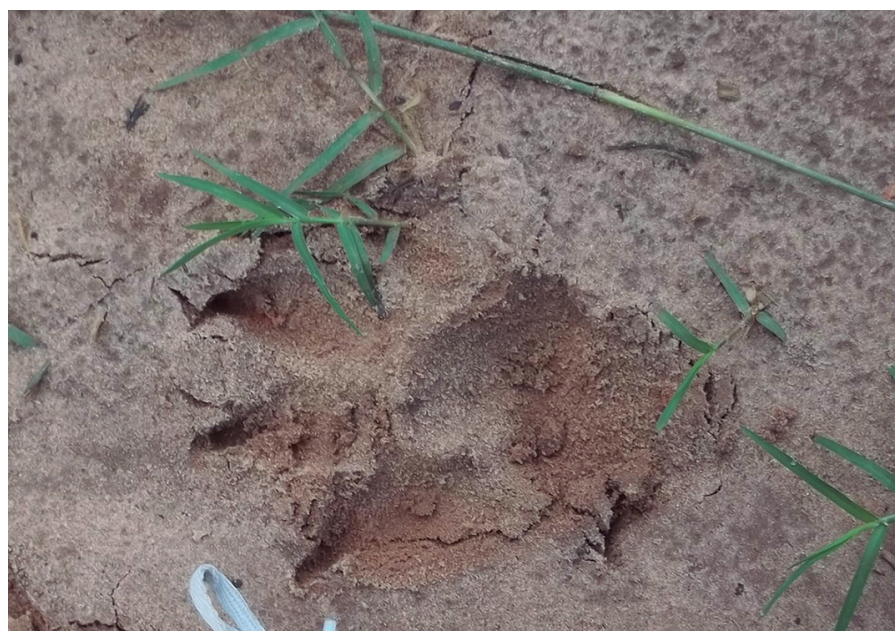

Rastro de lobo-guará observado na estrada ao lado da horta.

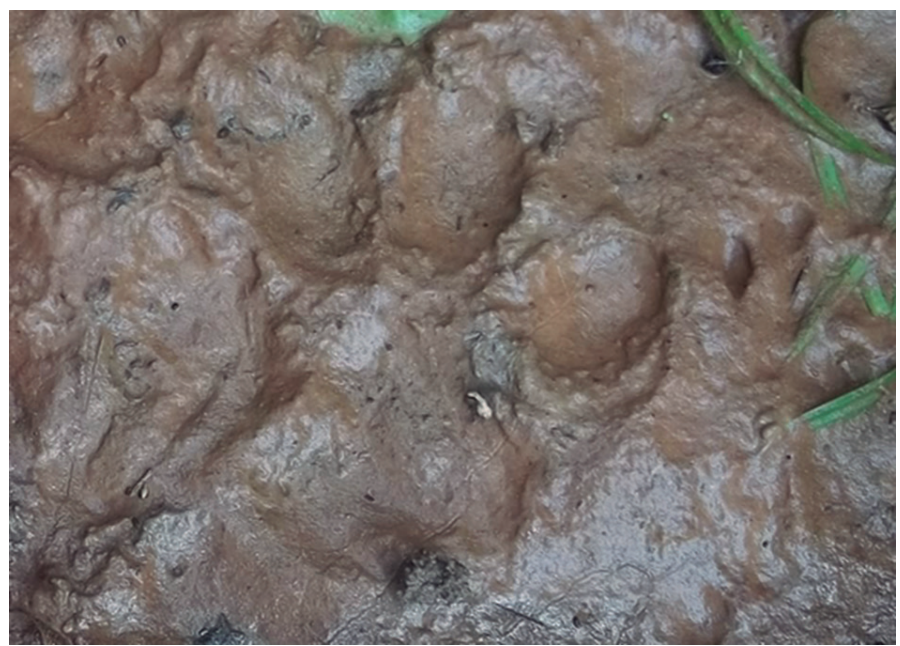

Rastro de filhote de onça-parda observado ao lado da Represa Prof. Jorge Jim. 


\section{REFERÊNCIAS BIBLIOGRÁFICAS}

ARGEL, M. et al. Aves do Brasil: Pantanal e cerrado. Editora Horizonte Geográfico, 2010.

ARRUDA, S. M.; VILLANI, A. Mudança conceitual no ensino de ciências. Caderno Catarinense de Ensino de Física, v.11, n.2, p.8899, 1994.

BECKER, M.; DALPONTE, J. C. Rastros de mamíferos silvestres brasileiros: um guia de campo. Rio de Janeiro: Technical Books, 2013.

CAMARGO, L. I. A. Composição florística e estrutura fitossociologia de um remanescente de Floresta Estacional Semidecidual no município de Botucatu/SP. Botucatu, 2009. 40f. Monografia - Faculdades Integradas Regionais de Avaré (Fira).

CARVALHO, C. T.; VASCONCELLOS, L. E. M. Disease, Food and Reproduction of the Maned-Wolf (Chrysocyon brachyurus) in Southeast Brazil. Revista Brasileira de Zoologia, v.112, n.3, p. 62740, 1995.

CHIARADIA, C. Dicionário de palavras brasileiras de origem indígena. São Paulo: Limiar, 2008.

EMA. Caminhos da ecoalfabetização na Escola do Meio Ambiente. 16p. Botucatu: Escola do Meio Ambiente, 2015.

- Guia pedagógico de rastros e vestígios de animais encontrados na área da Escola do Meio Ambiente. 48p. Botucatu: Escola do Meio Ambiente, 2013. 
EMA. Da Escola do Meio Ambiente (EMA) ao Sabiá-Laranjeira (Ave Nacional do Brasil). 48p. Botucatu: Escola do Meio Ambiente, 2011.

. O cerrado da Escola do Meio Ambiente traduzido em saberes para a sua preservação. 24p. Botucatu: Escola do Meio Ambiente, 2009.

Fomos vistos na Escola do Meio Ambiente. 6p. Botucatu: Escola do Meio Ambiente, 2008a.

Guia da fauna e da flora da Escola do Meio Ambiente. 72p. Botucatu: Escola do Meio Ambiente, 2008b.

ESTEVES, M. C. S. Biologia reprodutiva de Scinax fuscomarginatus, na represa do ribeirão Lavapés, Botucatu, SP (Amphibia, Anura, Hylidae). Botucatu, 2009. 40f. Monografia - IBB, Universidade Estadual Paulista "Júlio de Mesquita Filho" (Unesp)/câmpus Botucatu.

FERREIRA, D. Levantamento de mamíferos ocorrentes na área da Escola do Meio Ambiente. Avaré, 2008. 40f. Monografia - Faculdades Integradas Regionais de Avaré (Fira).

FONSECA, G. A. B.; RYLANDS, A. B. Edentata-The Newsletter of the IUCN Edentate Specialist Group, n.5, 2003. 88p.

GOMES, P. H. Levantamento fitossociológico de um fragmento de mata de brejo na área da Escola do Meio Ambiente (EMA), Botucatu/SP. Botucatu, 2008. 24f. Monografia - Faculdades Integradas Regionais de Avaré (Fira).

JUNIPER, T.; PARR, M. Parrots: a Guide to the Parrots of the World. Londres: Christopher Helm Editor, 2001.

LANGE, R. R.; SCHMIDT, E. M. S. Rodentia - Roedores silvestres (Capivara, Cutia, Paca, Ouriço). In: CUBAS, Z. S.; SILVA, J. C. R.; CATÃO-DIAS, J. L. Tratado de animais selvagens: Medicina Veterinária. 2.ed. São Paulo: Editora GEN/Roca, 2014. p.1.13768.

LOUGHRY, W. J.; DONOUGH, C. M. Comparisons Between Nine-Banded Armadillo (Dasypus novemcinctus) Populations in Brazil and the United States. Revista Biologia Tropical, v.46, n.4, p.1.173-83, 1998. 
MACEDO, N. A. Estabelecendo uma amizade entre o homem e os anfíbios anuros: uma questão de educação ambiental na Escola do Meio Ambiente, Botucatu-SP. Botucatu, 2009. 55f. Monografia - IBB, Universidade Estadual Paulista "Júlio de Mesquita Filho" (Unesp)/câmpus Botucatu.

MARTINS, S. G. Distribuição espacial das espécies Hedyosmum brasiliense Miq., Tabebuia umbellata (Sond.) Sandwith, Magnolia ovata (A.St. Hil.) Spreng. e Tapirira guianensis Aubl. Em um fragmento de floresta paludosa na Escola do Meio Ambiente (EMA) - Botucatu-SP. Bauru, 2009. 44f. Monografia - Universidade do Sagrado Coração (USC).

MOTTA-JÚNIOR, J. C.; TALAMORI, S. A.; VASCONCELLOS, L. A. S. Levantamento dos mamíferos do campus da Universidade Federal de São Carlos, estado de São Paulo, Brasil. Anais do VII Seminário Regional de Ecologia, v.VII, p.173-82, 1996.

NOWAK, R. M. Walker's Mammals of the World (Volumes I and II), 6.ed. Maryland: The Johns Hopkins University Press, 1999.

OSBORNE, R. Conceptual Change - for Pupils and Teachers. Research in Science Education, v.12, p.25-31, 1982.

PADULA, C. R. Levantamento de espécies de marsupiais na Escola do Meio Ambiente (EMA) de Botucatu (SP). Bauru, 2011. 26f. Monografia - Universidade do Sagrado Coração (USC).

PINTO, K. C. V. Levantamento qualitativo da avifauna na área da Escola do Meio Ambiente, Botucatu/SP. Bauru, 2009. 48f. Monografia - Universidade do Sagrado Coração (USC).

RECHE, A. M. Levantamento de roedores de pequeno porte em fragmentos naturais na EMA de Botucatu (SP). Bauru, 2013. 34f. Monografia - Universidade do Sagrado Coração (USC).

ROCHA, E. C.; DALPONTE, J. C. Composição e caracterização da fauna de mamíferos de médio e grande porte em uma pequena reserva de cerrado em Mato Grosso, Brasil. Revista Árvore, Viçosa , v.30, n.4, p.669-78, 2006.

SICK, H. Ornitologia Brasileira. Rio de Janeiro: Nova Fronteira, 1997. 


\section{SOBRE AS AUTORAS}

ELIZABETH MOREIRA DOS SANTOS SCHMIDT - Médica veterinária formada pela Universidade Federal do Paraná (UFPR)/ Curitiba (1997). Mestre em Ciências Veterinárias pela UFPR/Curitiba (2000). Doutora em Medicina Veterinária pela Faculdade de Ciências Agrárias e Veterinárias (FCAV) - Unesp/Jaboticabal (2008). Realizou pós-doutoramento na Universidade de Glasgow/ Reino Unido (2013) e na Universidade de Murcia/Espanha (20152016). Atualmente é professora assistente doutora do Departamento de Clínica Veterinária da Faculdade de Medicina Veterinária e Zootecnia (FMVZ) - Unesp/Botucatu.

ELIANA MARIA NICOLINI GABRIEL - Bióloga pelo Instituto de Biociências - Unesp/Botucatu. Mestre e doutora em Ecologia de Floresta pelo Instituto de Biociências - Unesp/Rio Claro. É especialista em Agricultura e Ecologia pela Universidade de Beer Sheva/Israel. Foi vencedora do III Prêmio do Instituto Ecofuturo de Educação para a Sustentabilidade, Projeto: Uma andorinha só faz verão. Atualmente é diretora da Escola do Meio Ambiente da Prefeitura Municipal de Botucatu/SP. 
Histórias e descrições biológicas

Profa Dra Elizabeth M. dos Santos Schmidt

Médica veterinária, professora e pesquisadora do

Departamento de Clínica Veterinária da

Faculdade de Medicina Veterinária e Zootecnia Unesp, câmpus Botucatu

Coordenação e orientação

Profa Dra Eliana Maria Nicolini Gabriel

Bióloga e diretora da Escola do Meio Ambiente do município de Botucatu

Desenhos que ilustram as histórias:

Anna Clara Nicolini Gabriel

Arte e aquarelas

Sibele Gimenez Martins

Bióloga e pesquisadora, ilustradora das publicações

da Escola do Meio Ambiente

Revisão

Prof. Dr. José Luis Chiaradia Gabriel

Biólogo, professor e pesquisador da Fira/Avaré, docente dos colégios

La Salle e Santa Marcelina, Botucatu (SP)

Agradecimentos

Fernanda Campagner

Monitora ambiental da EMA

Profa Dra Maria Auxiliadora Schmidt - UFPR

Walter Werner Schmidt

Secretaria Municipal de Educação de Botucatu/SP 


\section{Escola do Meio Ambiente}

Secretaria Municipal de Educação de Botucatu/SP

Endereço: Avenida José Ítalo Bacchi, s/n, Jd. Aeroporto, CEP 18.606-851

Endereço para correspondência: Praça Dom Luiz Maria de Santana, 176,

Centro, CEP 18.600-311, Botucatu/SP

Fone/Fax: (14) 3811-3183

http://www.botucatu.sp.gov.br/ema

emabotucatu@yahoo.com.br

Departamento Clínica Veterinária - Unesp

Faculdade de Medicina Veterinária e Zootecnia

Endereço: Rua Prof. Dr. Walter Mauricio Correa, s/n, bairro Unesp, câmpus de

Botucatu, CEP 18.618-681, Caixa Postal 560, Botucatu/SP 
SOBRE O LIVRO

Formato: $14 \times 21 \mathrm{~cm}$

Mancha: 23, $7 \times 43,16$ paicas

Tipologia: Horley Old Style 10,5/14

2016

EQUIPE DE REALIZAÇÃO

Coordenação Geral

Pedro Barros (Tikinet Edição Ltda.) 